\title{
Review \\ Co-Operativity between MYC and BCL-2 Pro-Survival Proteins in Cancer
}

\author{
Walter Douglas Fairlie ${ }^{1,2,3}$ (D) and Erinna F. Lee ${ }^{1,2,3, * \mathbb{D}}$ \\ 1 Olivia Newton-John Cancer Research Institute, Heidelberg, VIC 3084, Australia; doug.fairlie@onjcri.org.au \\ 2 School of Cancer Medicine, La Trobe University, Melbourne, VIC 3084, Australia \\ 3 Department of Biochemistry and Genetics, La Trobe Institute for Molecular Science, La Trobe University, \\ Bundoora, VIC 3084, Australia \\ * Correspondence: Erinna.Lee@latrobe.edu.au
}

check for

updates

Citation: Fairlie, W.D.; Lee, E.F. Co-Operativity between MYC and BCL-2 Pro-Survival Proteins in

Cancer. Int. J. Mol. Sci. 2021, 22, 2841. https: / / doi.org/10.3390/

ijms22062841

Academic Editors: Daniela Grifoni, Helena Elizabeth Richardson and Julia B. Cordero

Received: 18 February 2021

Accepted: 10 March 2021

Published: 11 March 2021

Publisher's Note: MDPI stays neutral with regard to jurisdictional claims in published maps and institutional affiliations.

Copyright: (c) 2021 by the authors. Licensee MDPI, Basel, Switzerland. This article is an open access article distributed under the terms and conditions of the Creative Commons Attribution (CC BY) license (https:/ / creativecommons.org/licenses/by/ $4.0 /)$.

\begin{abstract}
B-Cell Lymphoma 2 (BCL-2), c-MYC and related proteins are arguably amongst the most widely studied in all of biology. Every year there are thousands of papers reporting on different aspects of their biochemistry, cellular and physiological mechanisms and functions. This plethora of literature can be attributed to both proteins playing essential roles in the normal functioning of a cell, and by extension a whole organism, but also due to their central role in disease, most notably, cancer. Many cancers arise due to genetic lesions resulting in deregulation of both proteins, and indeed the development and survival of tumours is often dependent on co-operativity between these protein families. In this review we will discuss the individual roles of both proteins in cancer, describe cancers where co-operativity between them has been well-characterised and finally, some strategies to target these proteins therapeutically.
\end{abstract}

Keywords: apoptosis; MYC; BCL-2; BH3-only; BH3-mimetic; pro-survival

\section{The BCL-2 Family of Proteins Regulate Apoptosis}

There is a delicate balance within cells that dictates whether they live or die, and this exigency must be met to maintain a disease-free state. The BCL-2 family is an important group of proteins that holds tight rein on this counterpoise of whether a cell survives, or alternatively, is eliminated by the process of apoptosis (Figure 1) [1].

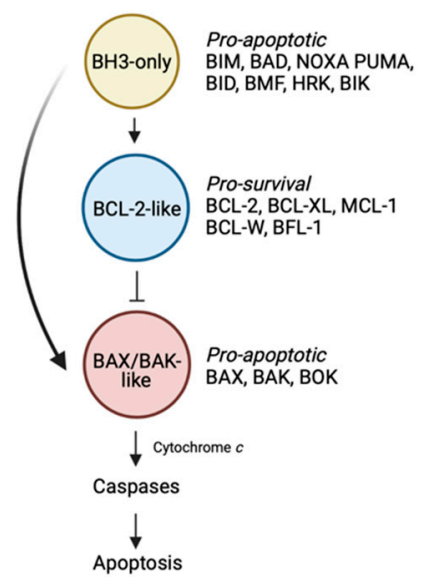

Figure 1. The BCL-2-regulated apoptotic pathway. The BH3-only proteins trigger the apoptotic cascade by either binding the BCL-2-like pro-survival proteins, displacing the BAX/BAK-like proteins, or alternatively in the case of certain members (e.g., BIM, BID, PUMA), by directly engaging and activating BAX/BAK. These events lead to BAX/BAK oligomerization followed by mitochondrial outer membrane permeabilisation, caspase activation and death. Figure created with Biorender.com. 
Within the BCL-2 family, there are proteins that promote cell death and others that enable cell survival. Of the cell death promoters, there are two sub-families. The first comprise the "BH3-only" proteins which trigger the apoptotic cascade [1]. Upon receipt of a death stimulus, these BH3-only proteins are transcriptionally upregulated, or posttranslationally modified, enabling them to act on downstream pro- and anti-apoptotic family members, thereby initiating the slippery slide to cell death. In mammals, there are eight main members including BIM, PUMA, BID, NOXA, BID, BAD, BMF and HRK. The second sub-family of death-promoting molecules are the "BAX/BAK-like" proteins [1]. This family which includes BAX, BAK and BOK are the downstream effectors of the family. These multi-domain proteins, once activated, oligomerise to form pores resulting in mitochondrial outer membrane permeabilisation. A consequence of this event is the release of apoptogenic factors such as cytochrome $c$ from the mitochondria into the cytosol, leading to activation of the cellular demolitionists, the caspases.

The last faction within the BCL-2 family are the "BCL-2-like" pro-survival proteins [1]. In mammals, there are five members: BCL-2 itself, BCL-XL, BCL-W, MCL-1 and BFL-1. In healthy cells, pro-survival proteins can be found in heterodimeric complexes with BAX or BAK preventing their oligomerisation [2]. Alternatively, pro-survival proteins can also bind to, and inhibit the ability of upstream $\mathrm{BH} 3$-only proteins to directly activate and induce oligomerisation of the BAX/BAK sub-family [2].

The rules of engagement describing the differential binding specificities of the proapoptotic proteins and pro-survival proteins are now well-defined and contribute to the highly tuned and ordered network of protein-protein interactions that dictate cell survival [3-5]. Serendipitously, the importance of the natural binding specificities that exist between the opposing factions of the BCL-2 family proved critical to the design of anticancer therapeutics targeting this pathway, which will be discussed later.

\subsection{The Role of Pro-Survival BCL-2-Like Proteins in Tumourigenesis}

Resisting cell death is a well-defined hallmark of cancer [6]. It is intuitive to think that aberrantly high levels of proteins that promote cell survival, or on the other hand, insufficient pro-death protein activity, can lead to tumourigenesis. In line with this, the identification of genetic lesions in human cancers [7-9], together with the use of genetically engineered mouse models $[10,11]$ that lead to both these states, provided convincing evidence supporting an important role for members of the BCL-2 family in cancer.

The founding member of the BCL-2 family is BCL-2 itself. The gene was first identified during the heyday of oncogene discovery through the study of chromosomal rearrangements. Indeed, BCL-2 was discovered by mapping a $t(14 ; 18)$ translocation in an acute B lymphocytic leukaemia (ALL)-derived cell line [8]. The same chromosomal translocation was later observed in other haematological malignancies including $80 \%$ of follicular B-cell non-Hodgkin's lymphomas (FL) [12-14], 20\% of diffuse large B-cell lymphoma (DLBCL) [14], and more rarely in B-cell chronic lymphocytic leukaemia (CLL) (about $2-4 \%$ of cases) [14-16]. The gene for BCL-2 was cloned by three separate groups from FL, DLBCL and normal cells $[8,12,17-19]$. It was subsequently discovered through molecular analysis, that the translocations in these different diseases, though cytogenetically identical, arise via differing mechanisms [20]. However, despite these molecular differences, the shared outcome of this translocation event was the placement of the BCL2 gene under the control of the immunoglobulin heavy $(\operatorname{IgH})$ chain gene enhancer, resulting in the aberrant high-level constitutive expression of BCL-2.

Importantly, it soon came to light that it was this high level of BCL-2 expression, and not the presence of the $t(14 ; 18)$ chromosomal translocation, that was important in tumourigenesis [21,22]. High levels of BCL-2 expression, comparable to that observed in $\mathrm{t}(14 ; 18)$-containing haematological malignancies, is also seen in FL [23], CLL [24,25], DLBCL [26], multiple myeloma (MM) [27] and mantle cell lymphoma (MCL) [28] despite the absence of the $t(14 ; 18)$ translocation. Multiple mechanisms have now been reported by which deregulation of BCL-2 expression can occur. These include the deregulated 
expression of BCL-2 transcriptional activators [29], somatic mutations in the BCL-2 promoter region [29], loss of microRNAs that negatively regulate BCL-2 [30-33], BCL-2 gene amplification or its transcriptional upregulation through constitutive activation of the NF- $\mathrm{kB}$ pathway [34]. Notably, this phenomenon is not restricted to just blood cancers but also extends to solid cancers such as lung [35], prostate [36], liver [37], and breast carcinomas [38] in which high levels of BCL-2 expression is observed even in the absence of $B C L-2$ gene rearrangements.

Accordingly, detection of the $t(14 ; 18)$ translocation has little prognostic significance. Instead, it is the high levels of BCL-2 protein expression that serves to predict poor prognosis, reduced overall and disease-free survival, and recurrence in cancers [39]. For example, enhanced expression of BCL-2 is associated with the development of androgen-refractory prostate cancer [40], whilst in CLL, higher expression of BCL-2 is an adverse prognostic feature [41]. High BCL-2 expression also dictates poorer patient outcome following standard chemotherapy $[22,39,42-44]$. However, it should be noted that the role of BCL-2 expression as a prognostic marker also does not always hold up $[35,45,46]$ such as in studies of advanced head and neck carcinoma and bladder cancer [47,48]. In fact, in some cases, BCL-2 expression correlates with improved clinical outcome, for example in patients with Estrogen Receptor (ER)- and Progesterone Receptor (PR)-positive breast cancer who received adjuvant endocrine therapy $[49,50]$.

\subsection{BCL-2-Defining a New Class of Oncogenes}

It became increasingly evident that overexpression of BCL-2 contributes to tumourigenesis. The question then was-how does this occur? The discovery of BCL-2 not only identified a novel oncogene but perhaps more importantly, defined a paradigm-shift in what we understood about oncogenes. The landmark study using cytokine (IL-3)-dependent cell lines in culture demonstrated that, in contrast to all other known oncogenes at that time which promoted deregulated proliferation, overexpression of BCL-2 instead protected cells against death by apoptosis following cytokine deprivation [9]. These findings underlined that it is not just defects in the control of cellular proliferation that can promote tumourigenesis, but that defects in cell death leading to unwanted survival, were also important. Furthermore, the studies on the anti-apoptotic properties of BCL-2 defined for the first time that distinct genetic programs control cell proliferation versus cell survival. Now, apoptosis is widely accepted as a prominent tumour-suppressive function and that the inhibition of this pathway (such as through the overexpression of pro-survival proteins) is a key hallmark of cancer and drug resistance [6].

Subsequent to the discovery of the function of the first BCL-2 family member, additional members of the family were identified largely based on sequence conservation of up to four regions of homology known as $\mathrm{Bcl}-2$ homology $(\mathrm{BH})$ domains. These included four additional pro-survival members namely BCL-XL, BCL-W, MCL-1 and BFL-1, all of which have since been shown to contribute to the survival of various cancers.

\subsection{Other Pro-Survival Members of the BCL-2 Family and Their Contributions to Tumourigenesis}

A comprehensive study examining somatic copy-number alterations (SCNAs) in frequently altered genomic regions in over 3000 cancer specimens, from broadly 26 histological types, identified key genes with potential causal roles in tumourigenesis [51]. Amongst the gene families enriched included members of the BCL-2 family. Consistent with the notion that evasion of cell death is a hallmark of cancer [6], the pro-survival proteins BCL-XL and MCL-1 were found in amplification peaks when compared to non-cancerous samples, whilst pro-apoptotic proteins such as BOK and PUMA were identified in deletion peaks. 


\subsubsection{MCL-1}

The gene for MCL-1 was discovered as an early response gene induced during the differentiation of a human myeloid leukaemia cell line [52]. Strikingly, one of the most common focal amplifications (1q21.2) detected (in 10.9\% of all cancers) contains the MCL-1 gene. Amplification of this region has been previously reported in lung adenocarcinoma [53,54], breast cancer [51], and melanoma [55]. Validation that amplified MCL-1 is the contributing factor in cancers came when knockdown of MCL-1 led to a significant reduction in cell growth in MCL-1-amplified cell lines, but not MCL-1-unamplified lines [51]. Like BCL-2, multiple mechanisms exist to give rise to high levels of MCL-1. These include microRNA deregulation, where mir-29b downregulation leads to increased MCL-1 expression in CLL and cholangiocarcinoma $[31,56]$ or upregulation of MCL-1 via deregulated external stimuli such as through vascular endothelial growth factor (VEGF) or Interleukin-6 signalling in multiple myeloma and cholangiocarcinoma [57,58]. High levels of MCL-1 are also found in blood cancers such as CLL, ALL, FL [59-61] and is associated with chemoresistance and disease severity [59-62].

\subsubsection{BCL-XL}

Like MCL-1, BCL-XL is one of five genes encompassed in a region of amplification (on 20q11.21) [51] that has been reported in lung cancer [63], giant-cell tumour of bone [64] and embryonic stem cell lines $[65,66]$. Using the same approach by which MCL-1 was validated as the key survival factor for MCL-1-amplified cancer cells, BCL-XL was knockdown in cell lines in which BCL-XL was amplified, resulted in a pronounced reduction in viability [51]. As with most pro-survival members of the BCL-2 family, elevated levels of BCL-XL have also been found in a number of different blood cancers. High levels of BCL$\mathrm{XL}$ have been reported in multiple myeloma and correlates with increased chemoresistance, although BCL-2 appears to feature more prominently in this cancer type [27,67]. However, its role as a predictor of clinical outcome for multiple myeloma remains debatable [68]. Expression of BCL-XL has also been implicated in the development and chemoresistance of $\mathrm{Bcr} / \mathrm{Abl}+$ chronic myelogenous leukaemia as this pro-survival protein is a transcriptional target of signal transducer and activator of transcription (STAT) 5 which is involved in the anti-apoptotic activity induced by Bcr-Abl-mediated leukemogenesis [69]. In a study using cancer genomics data sets derived from over 5000 tumour samples from 20 cancer studies to identify cancer types with significant amplification of BCL-XL (The cBio Cancer Genomics Portal [70]), both colorectal cancer and cervical cancer demonstrated the highest percentage of BCL-XL gains and amplifications across all cancer types analysed [71]. In particular, BCL-XL has been identified as a driver in colorectal tumourigenesis and cancer progression [72].

\subsubsection{BFL-1}

Unlike its other more well-characterised siblings, the role of BFL-1 (or A1 in mice) in tumourigenesis is perhaps not as far advanced. However, multiple studies are now pointing to an important role for it in tumour progression. Elevated levels of BFL-1 have been observed in B-cell CLL, AML, MCL and primary mediastinal large B-cell lymphoma [73-76] and contribute to chemoresistance and disease progression. For example, in B-cell CLL patients, BFL-1 levels were significantly higher in patients with no response to last chemotherapy as compared to patients that responded, or who had not required treatment [76]. Likewise, high BFL-1 expression correlated with more severe cases of CLL, indicating a potential prognostic role for BFL-1 [74]. Aberrant BFL-1 expression has been documented in various non-haematological malignancies including stomach [77] and breast cancers, especially in advanced breast cancer suggesting an association with later and more severe disease stages $[78,79]$. Overexpression of BFL-1 has also been implicated in melanoma cell survival although results have varied between studies as to its absolute essentiality for survival [80-85]. 


\subsubsection{BCL-W}

Perhaps the pro-survival member that has received the least attention in the context of tumorigenesis is BCL-W. Despite relatively few studies, BCL-W has been found to be significantly overexpressed in a wide range of human B-cell lymphomas, including Burkitt Lymphoma (BL), diffuse large B-cell lymphoma (DLBCL) and Hodgkin lymphoma patient samples and cell lines [86-88]. As with BCL-2 and MCL-1, for which deregulation of the microRNA control of their expression has been described in cancer, miR-133b deregulation has been observed in bladder cancer, colorectal carcinoma and lung cancer leading to BCL-W overexpression in these cancers [89-91].

\subsection{Pro-Apoptotic Proteins in Tumourigenesis}

Whilst not a key focus of this review, it should also be noted that loss-of-function or deregulation of pro-apoptotic members of the family have also been implicated in tumourigenesis. For example, Bak mutations have been reported in human gastric and colorectal cancers, predisposing those patients to the development of these gastrointestinal malignancies [92]. Loss-of-function mutations in BAX have been detected in haematological and colorectal malignancies $[93,94]$ and downregulation of BH3-only proteins such as BIM due to various mechanisms such as homozygous deletion or promoter hypermethylation has been observed in MCL, DLBCL and BL $[7,95,96]$.

The oncogenic potential of dysfunctional apoptosis is inarguable. Overexpression of pro-survival proteins likely promotes tumourigenesis by keeping cells that are otherwise programmed to die, alive. In so-doing, this enhanced resistance to dying increases their risk of acquiring additional oncogenic mutations, including ones that deregulate the control of cellular proliferation such as MYC.

\section{MYC: A Master Transcription Factor}

MYC refers to a family of three proto-oncogenes (c-MYC, MYC; n-MYC, MYCN, $l-M Y C$, MYCL) that were first identified by their homology to $v-M Y C$, an avian myelocytomatosis MC29 retrovirus gene capable of cellular transformation [97-100]. The MYC oncoproteins are all transcription factors consisting of an $\mathrm{N}$-terminal transregulatory domain and a Cterminal DNA-binding and dimerisation domain. The $\mathrm{N}$-terminal region is not particularly well-conserved between family members apart from six short regions of homology ("MYC boxes") that enable association with different binding partners, or which can be modified in different ways, leading to diverse functional outcomes including regulation of MYC stability/degradation, chromatin remodelling, histone acetylation and enhancing promotor affinity. The C-terminal region is, in contrast, highly conserved between MYC proteins and comprises basic (b), helix-loop helix (HLH) and leucine-zipper (ZIP) (collectively "bHLH-Zip") subdomains. The HLH and ZIP domain enable MYC to associate with the related bHLH-Zip protein, MAX, forming obligate heterodimers required for binding to enhancer-box (E-box) sequences within the promotors of MYC target genes [101-103], particularly those located proximal to CpG islands [104,105]. However, where MYC-MAX dimers bind is concentration dependent, and also includes enhancers, degenerate E-boxes, as well as some sequences without an E-box [106].

Estimates of the number of genes regulated by MYC vary, though is certainly in the thousands [107-110], and could perhaps include every active gene within a cell [111,112]. This is in part due to the abundance of E-box motifs within the genome, as well as the aforementioned capacity to bind outside of these sites. Not surprisingly, MYC has been implicated in regulating essentially every basic cellular function including cell cycle progression, differentiation, growth, metabolism, DNA replication and apoptosis as well as more specific functions which, amongst many others, includes cell adhesion, epithelial-mesenchymal transition and angiogenesis, all of which are all important in cancer metastasis. 
As the range of these functions and the literature describing them is so vast, we will confine any detailed discussion on how MYC regulates these processes to just the one that is most relevant to this review, namely apoptosis, which for obvious reasons is the predominant role for MYC and its co-operativity with BCL-2 (see Sections 3 and 4 below). Nevertheless, it is informative to first provide some general background on MYC regulation/deregulation and how it contributes to tumourigenesis.

\subsection{Mechanisms of MYC Activation and Its Deregulation in Cancer}

MYC is referred to as an "immediate early" gene. The MYC protein, is generally present at very low levels in normal or quiescent cells but is rapidly induced following mitogenic signals transduced via multiple cellular pathways including MAPK, WNT, NOTCH, and PI3K that are also frequently deregulated in cancer [113-119]. MYC-target gene mRNAs, as well as long non-coding RNAs, tRNAs and microRNAs, are transcribed by all three RNA polymerases (Pol I, Pol II, Pol III) [120-122].

In cancer, MYC levels are greatly enhanced, and in some cases, by orders of magnitude [112]. This is a consequence of a number of distinct possible mechanisms. The first of these to be discovered was the upregulation of v-MYC by insertion of a retroviral promoter by another avian (leukosis) retrovirus [123,124]. Importantly, MYC is unlike many, if not most, other oncogenes in that it does not need to be mutated to unleash its oncogenic potential. Rather, increased expression alone is sufficient to promote tumorigenesis. Most common of the mechanisms by which this occurs is gene amplification where increased MYC copy number can result in increased expression [125]. In some human cancers, the MYC loci can also be disrupted by chromosomal translocations. This occurs in essentially all Burkitt's lymphoma where the MYC gene on chromosome 8 is translocated into one of several heavy and light chain immunoglobulin loci on chromosome 14 (i.e., $\mathrm{t}(8: 14)$ translocation), driving high levels of MYC expression [126,127]. Other important mechanisms that lead to high-level MYC expression include transcriptional upregulation due to deregulated upstream signalling pathways such as WNT, PI3K and NOTCH [115,116,119], stabilisation of MYC mRNA [128], increased export of MYC from the nucleus leading to increased MYC translation $[129,130]$, reduced MYC degradation via loss of the ubiquitin ligases $\mathrm{SCF}^{\mathrm{Fbw}} 7$ and $\mathrm{SCF}^{\mathrm{Skp} 2}$ or mutations within different regulatory regions, especially at threonine 58 in the MYC degron (an interaction site for $\mathrm{SCF}^{\mathrm{Fbw} 7}$ ) [128,131-134], or stabilisation of the protein by phosphorylation (e.g., by ERK or GSK3) $[118,135]$.

\subsection{Mechanisms of MYC Deregulation in Promoting Tumourigenesis}

Apart from early reports on the cell-transforming capacity of $v-M Y C$, there are multiple lines of evidence supporting the importance of deregulated MYC expression in driving tumour development and progression. These have been reviewed extensively over the years but include indirect observations, as well as direct connections with tumourigenesis in experimental animal models [136]. For example, as described above, the levels of MYC are often elevated in tumours relative to non-cancerous tissue of the same origin. In patients, high MYC levels are often also associated with poor prognosis [137-139]. Cells that overexpress MYC take on characteristics of tumour cells, proliferating and growing more rapidly, whilst ablation of MYC results in the opposite effect [140]. Similarly, transgenic mouse models have shown that MYC overexpression results in increased tumourigenesis, whilst deletion or reduction in MYC levels, or its inhibition following expression of an engineered dominant negative mutant, can eliminate tumour development in certain models [141-143].

Although the combined evidence for the role of MYC in cancer is compelling, the mechanisms by which high levels of MYC drive tumourigenesis are more contentious [106]. Whilst it is clear increased MYC levels can cause cells to cycle more rapidly and to induce quiescent cells to renter the cell cycle, even in the absence of growth factors [144-146], MYC itself is actually a relatively weak transcription factor with expression of many specific target genes often increasing by less than two-fold [147,148], even when MYC levels are 
significantly upregulated. Furthermore, which specific genes are important for cellular transformation has yet to be conclusively established though changes in the expression (upregulation and suppression) of at least 40 MYC target genes have been implicated [149]. It has also been proposed that the increase in global (rather than specific) RNA levels due to increased genome-wide transcription could lead to oncogenesis. Increased MYC might also drive the formation of MYC-MAX dimers and increased affinity for, and occupation of specific gene promoters [150]. More recently, it has also been argued that target geneindependent functions of MYC associated with its vast interactome, including promotion of transcription termination upon stalling RNA Polymerase II, and its ability to coordinate transcriptional elongation with DNA replication and cell cycle progression, are likely critical factors in the mechanisms by which MYC promotes tumorigenesis [106].

Regardless of the specific details of these mechanisms, one process that has been inextricably linked to MYC overexpression is the induction of apoptosis. Whilst it might appear counterintuitive that increased MYC can lead to increased apoptosis in the context of tumourigenesis, the associated upregulation of oncogenic pro-survival proteins to counter this effect is a prominent feature of the development of some tumours. In the following section, we will discuss the roles of MYC in inducing apoptosis in more detail, and then review the mechanisms underlying the co-operativity between these two important signalling pathways in cancer.

\section{MYC-A Driver of Apoptosis}

In the early days, the oncogenic potential of MYC was classically attributed its ability to drive cell-cycle progression and the hyperproliferation of cells. Paradoxically, MYC expression in late passage fibroblasts is associated with tumours that grow less aggressively and with decreased ability to metastasise, as compared to for example RAS-expressing tumours, with cell loss by apoptosis commonly observed [151]. This ability of MYC to induce or sensitise cells to apoptosis, regardless of the phase of the cell cycle, was subsequently demonstrated in various cell types including factor-dependent myeloid cells, fibroblasts and self-reactive T-cells [152-154]. Furthermore, the level of MYC expression was shown to positively correlate with the extent of apoptosis induced both in vitro and in vivo $[153,155]$. Here, careful rheostat-like control of MYC levels demonstrated that a modest increase of MYC expression enhanced transformation, whilst robust expression led to significant apoptosis instead [155]. Notably, the domains on MYC that are responsible for conferring its apoptotic capacity overlap with regions of the protein required for its other well-accepted roles in transformation, sequence-specific DNA binding, MAX dimerisation and transcriptional activation [153]. Hence, whether the proliferation or apoptotic program is engaged is dependent on the operational threshold at which MYC triggers these distinct outputs, leading to dramatically distinct outcomes. This threshold is seemingly exquisitely dependent on the internal state of the cell and its microenvironment [155].

\subsection{Mechanisms by Which MYC Induces Apoptosis}

This latent or intrinsic tumour suppressor function of MYC, mediated by its ability to induce apoptosis has been heavily investigated. Moreover, the molecular mechanisms describing the crosstalk between MYC signalling and apoptosis induction is generally wellunderstood and can be broadly dichotomised into P53-dependent versus P53-independent mechanisms (Figure 2). 


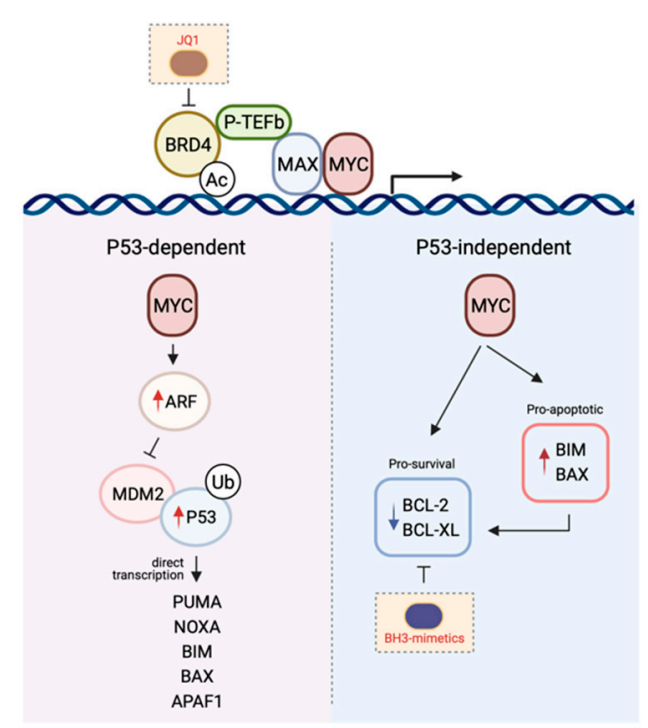

Figure 2. The mechanisms by which MYC induces apoptosis. The P53-dependent pathway to MYCinduced death is primarily mediated by the ARF-MDM-P53 axis following the upregulation of ARF expression by MYC. This leads to the stabilisation of P53 and the induction of P53 pro-apoptotic target genes. In contrast, the P53-independent pathway to MYC-induced apoptosis is reliant on the direct transcription of pro-apoptotic genes or the repression of pro-survival protein expression. Given the cooperativity between MYC signalling and the BCL-2-regulated apoptotic pathway in promoting tumourigenesis, combining drugs targeting both arms (e.g., MYC with JQ1, BCL-2 pro-survival proteins with $\mathrm{BH} 3$-mimetics) is a promising therapeutic avenue (see Section 5). Figure created with Biorender.com.

\subsubsection{P53-Dependent MYC-Induced Apoptosis}

In a healthy cell, P53 is normally short-lived and found at low levels. However, following receipt of a stress stimulus or DNA damage, it is stabilised and accumulates in order to exert its inhibition on cell cycle progression or cell survival. The tumour suppressive role of the transcription factor P53 is attributed to its ability to induce apoptosis [156]. This occurs mostly by direct transcriptional activation of the BH3-only protein PUMA, and to a lesser extent NOXA [157-161]. In addition, P53 is also thought to regulate BIM expression, although it is less clear whether this occurs via indirect $[162,163]$ or direct mechanisms of transcriptional regulation [164-166]. In addition to BH3-only proteins, both BAX and APAF1 have also been shown to be transcriptional targets of P53, though their participation in P53-mediated apoptosis is likely cell-type dependent [167-169].

Concurrent with P53 accumulation, expression of the P53-target gene MDM2 is also induced $[170,171]$ which serves as a negative-feedback loop as MDM2 binds to, and targets P53 for proteasomal degradation, inhibiting its transcriptional activity [172-174]. Upstream of this P53/MDM2 node is the tumour suppressor ARF, which is perhaps the second most commonly deleted or mutated locus in cancer, behind P53. The ARF protein binds to MDM2, inhibiting MDM2-induced P53 degradation and transactivational silencing, and can do so as a ternary complex [175-178]. Alternatively, ARF has also been proposed to inhibit MDM2-mediated nuclear export of P53 into the cytoplasm hence leading to the stabilisation of the latter $[176,179]$.

The importance of the ARF-MDM2-P53 axis in MYC-induced apoptosis [180] is supported by several lines of evidence. Overexpression of MYC in cells leads to the induction of ARF expression and P53-dependent apoptosis, and the loss of ARF or P53 renders cells highly resistant to the deleterious effects of elevated MYC levels [181]. Consistent with this, in the face of MYC overexpression, wild-type cells that sustain P53 mutations and ARF hemizygous cells bearing loss of ARF are conferred a selective advantage enabling their continuous proliferation $[181,182]$. Perhaps the most elegant and convincing evidence was provided by studies carried out in the E $\mu$-MYC transgenic mouse model. Tumour 
latency in this mouse model is typically six-months prior to the onset of disease, with high levels of apoptosis detected in the B-lymphocyte compartment consistent with the induction of apoptosis due to high MYC levels [183]. However, in approximately half of the spontaneous tumours that do arise this model, inactivation of the ARF-MDM2-P53 axis, through either ARF (biallelic deletion), P53 loss of function (by mutation or biallelic deletion), or overexpression of MDM2, is observed [182]. In addition, ARF or P53 deletion markedly accelerated lymphomagenesis in the context of the E $\mu$-MYC transgenic mouse model [184]. These and other studies (which due to space limitations have not been included in this review) underscore the role of the ARF-MDM2-P53 axis in delivering the fatal blow induced by MYC overexpression.

\subsubsection{P53-Independent MYC-Induced Apoptosis}

Intriguingly, high levels of MYC can still kill cells in the absence of P53, strongly suggesting that P53-dependent signalling is in fact not obligatory for MYC-induced apoptosis [185]. Logically, it makes sense that the MYC-induced apoptotic program has in place P53-independent mechanisms so that even in the context of P53 loss-of-function, which is a frequent event in oncogenesis, cells still retain the capacity to protect themselves in the face of deregulated cellular proliferation. Not unexpectedly, though tellingly, the mechanisms enabling the P53-independent crosstalk between MYC and apoptosis is largely mediated by members of the BCL-2 family as a consequence of the transcriptional activity of MYC.

A key mediator implicated in MYC-induced apoptosis is the BH3-only protein BIM. Independent of P53 status, BIM expression is transcriptionally induced following binding of MYC to the BIM promoter, inducing BIM overexpression [10,186,187]. Perhaps the most convincing evidence supporting a role for BIM induction in mediating the tumour suppressive function of MYC was provided in experiments using MYC mutants incapable of inducing the expression of this pro-apoptotic protein. Here, mice transplanted with haematological cells expressing these MYC mutants succumbed to lymphomas more rapidly than their wild-type counterparts [186]. Notably, these mutants had no impact on the proliferative potential of MYC, further emphasising the importance of the pro-apoptotic capacity of this oncogene in tumour surveillance. Importantly, this observation has been seen in human Burkitt's lymphoma where BIM expression is virtually absent in tumours carrying mutant MYC $[186,188]$. The role for BIM as a mediator of MYC-induced apoptosis extends beyond that seen in lymphomagenesis and has also been observed in multiple solid tissues [187].

In addition to BIM, MYC can also engage E-boxes in the BAX promoter to upregulate BAX expression and induce apoptosis [189]. Notably, apoptosis can still ensue following MYC overexpression in $B A X^{-/-}$cells, though not to the same extent as in the $B A X^{+/+}$ control cells, suggesting other mechanisms are also involved in cell killing (e.g., via BIMinduced BAK activation). MYC has also been shown to repress both mRNA and protein expression of pro-survival members such as BCL-2 or BCL-XL [190,191], hence inhibiting the induction of apoptosis directly.

\section{Cooperativity between Myc and the Bcl-2-Regulated Apoptotic Program in Tumourigenesis}

\subsection{Cooperativity between MYC and Elevated Pro-Survival Proteins}

Deregulated MYC expression is a common event in tumour cells indicating that this is an essential step in tumourigenesis. It therefore makes sense for cells to have developed a built-in failsafe program to limit the resulting unchecked cell proliferation. The proliferative advantage conferred by MYC overexpression cannot be disentangled from its ability to induce apoptosis, and hence its deregulation should be lethal to a cell. It is thus reasonable to conclude that whilst MYC deregulation is an essential step in tumourigenesis, cells also need to acquire a secondary block in apoptosis signalling preventing their demise. The observation that heightened sensitivity to apoptosis caused by ectopic MYC expression is observed in premalignant cells, but not after malignant transformation provides evidence 
that tumour cells do acquire specific mechanisms to blunt the pro-apoptotic effects of MYC deregulation [192].

In the same way deregulated MYC alone does not lead to full malignant transformation, the overexpression of BCL-2 pro-survival proteins alone is also similarly insufficient. The $t(14 ; 18)$ chromosomal translocation leading to the deregulated expression of BCL-2 is now a well-established oncogenic hit, particularly in B-cell lymphomas. Landmark studies using transgenic mice to recapitulate this translocation, where the BCL-2 gene was linked to the immunoglobulin heavy-chain gene enhancer, resulted in the polyclonal expansion of B lymphoid cells, in particular immature and mature B cells, as well as Ig-secreting plasma cells, and enabled their prolonged survival in vitro [193-195]. However, tumour incidence observed in these mice was unexpectedly low, with only $5-20 \%$ progressing through, and only at an advanced age (one to two years), to a monoclonal lymphoma or plasmacytoma, instead of recapitulating the follicular lymphoma characteristic of the $t(14 ; 18)$ chromosomal translocation in humans. In addition, IL-3 dependent myeloid progenitor cells overexpressing BCL-2 failed to produce tumours when injected into mice $[9,196]$. Intriguingly, this translocation has been detected in healthy individuals with only a small number expected to develop lymphomas [197]. The slow progression to tumour manifestation in the E $\mu$-BCL-2 mice and the existence of the $t(14 ; 18)$ translocation in healthy individuals, strongly suggest that the overexpression of BCL-2 as a consequence of this genetic aberration can occur beyond the context of malignancy and/or hyperplasia and likely precedes other key oncogenic steps (such as secondary genetic aberrations) required for full neoplastic transformation.

Consistent with these notions, the progression of follicular lymphoma to a more aggressive intermediate or high-grade lymphoma occurs in the majority of patients where the transformed lymphomas retain the $t(14 ; 18)$ translocation but also acquire new chromosomal abnormalities [198,199]. Notably, a new translocation of the MYC gene into the immunoglobulin locus is observed in $~ 10 \%$ of such transformed lymphomas (so-called "double-hit" lymphomas) [200]. This observation extends to other cancer types too, for example non-Hodgkin lymphoma [201], germinal centre B-cell lymphoma [202], and acute lymphoblastic leukaemia [203,204] where concurrent activation of BCL-2 and MYC occurred leading to their elevated levels.

These clinical observations that BCL-2 and MYC cooperate in neoplastic transformation had in fact already been proven experimentally. Firstly, early in vitro studies demonstrated that BCL-2 and MYC cooperated to favour the growth of pre-B and B cells $[9,205]$. Further compelling results were then derived from mouse experimental models. Landmark studies in mice doubly transgenic for BCL-2 and MYC developed tumours much more rapidly than mice expressing either transgene alone [11]. In addition, almost $50 \%$ of the high-grade diffuse large-cell immunoblastic lymphomas that arose in the BCL-2 transgenic mice harboured rearrangements in the MYC gene [206,207]. Validation that a blockade of apoptosis due to the sustained overexpression of BCL-2 was a required step during MYC-driven tumourigenesis was shown in a mouse model of lymphoblastic leukaemia where removal of this BCL-2 reliance using an inducible system led to leukaemia remission and prolonged survival of the mice [208].

Mechanistically, this cooperativity between MYC and BCL-2 was proven to be due to the ability of BCL-2 overexpression in mitigating the apoptotic effects of deregulated MYC expression, without affecting MYC's mitogenic function [209-211]. This interaction between MYC and BCL-2 described a novel mechanism for oncogene cooperation that differed from the well-accepted cooperativity between oncogenes such as MYC and activated RAS.

Since these landmark studies with MYC and BCL-2, cooperativity with MYC in the promotion of malignant transformation has since been shown to extend beyond BCL2 itself, and applies to other pro-survival members of the BCL-2 family. For example, overexpression of MCL-1 in multiple hematopoietic lineages accelerated MYC-driven tumourigenesis [212,213] whilst high levels of BCL-XL cooperates with deregulated MYC 
to lead to plasma cell malignancies and highly malignant leukaemia [214-216]. Consistent with these observations in mice, the most frequent other focal SCNA in human cancers harbouring an amplification in either MCL-1 or BCL-XL was amplification of the region carrying MYC (in 2/3 of these cases) [51].

\subsection{Cooperativity between MYC and Endogenous Pro-Survival Proteins}

The studies described above convincingly demonstrated that deregulated cell proliferation and impaired cell death are potently synergistic in tumourigenesis. However, these scenarios all involved the enforced overexpression of the pro-survival protein compartment, in particular as a consequence of a chromosomal translocation. The question therefore remained as to whether endogenous levels of the pro-survival proteins would be sufficient to sustain the malignant growth and survival of MYC-induced cancers. Intriguingly, deletion of endogenous BCL-2 itself did not reduce the incidence or delay the onset of E $\mu-M Y C$ lymphomagenesis [217], despite earlier studies demonstrating the critical role of overexpressed BCL-2 in mediating this oncogenic cooperativity. These findings suggested that during the genesis of MYC-driven lymphoma, the acquisition of pro-oncogenic hits takes place at a stage when BCL-2 is dispensable. As the mice bearing an E $\mu-\mathrm{Myc} / \mathrm{Bcl}-2^{-/-}$ haematopoietic compartment only showed significant compromise in the survival of the mature B cell subset [217], this suggested that it is likely the pro-B and/or pre-B cells (or earlier progenitors) that are responsible.

The pro-survival proteins BCL-XL and MCL-1 were obvious candidates as factors enabling this sustained tumour growth as they are expressed at several stages of B lymphopoiesis and are critical to the survival of B lymphoid progenitors and/or precursors. It was subsequently shown that BCL-XL is essential for E $\mu$-MYC-induced lymphoma growth, but loss of this protein did not significantly impact the sustained growth of such tumours [218]. Instead, it is MCL-1 which appears to be the key factor driving the sustained growth of E $\mu-M Y C$ lymphoma and even the loss of a single allele was enough to lead to complete regression in $20 \%$ of tumours [219].

There is overwhelming evidence to demonstrate that endogenous or overexpressed BCL-2 pro-survival proteins contribute to oncogenesis by permitting the survival of nascent neoplastic cells for long enough such that other advantageous oncogenic mutations, for example in MYC, can be acquired. Whilst not a focus of this review, loss of effective cellular pro-apoptotic function (e.g., loss of BIM [10], or BAX [220]) can also lead to cooperativity with MYC to accelerate tumourigenesis. These studies provide strong evidence that inhibition of MYC-induced apoptosis is a key enabling feature of the cooperation between pro-survival BCL-2 proteins and MYC.

\section{Therapeutic Strategies Targeting Bcl-2 and MYC}

Given the importance of MYC and BCL-2 proteins in cancer, it is unsurprising that there has been considerable interest in the discovery of drugs that can target both these proteins. In this section we discuss efforts around the discovery of drugs targeting these proteins individually, and then how some of these have been applied in combination.

\subsection{Drugs Targeting BCL-2 Proteins}

Although there was considerable early interest in the development of antisense oligonucleotide strategies to reduce BCL-2 levels in tumour cells, and some such as Oblimersen sodium showed some promising activity in clinical trials [221,222], this approach has now been overtaken with the advent of small molecule direct inhibitors of BCL-2 proteins. When the first three-dimensional structures of BCL-2 proteins became available, especially those in complex with their natural ligands, the BH3 domains of pro-apoptotic proteins, they immediately suggested a potential strategy to develop small molecule drugs that could induce apoptosis through mimicry of this interaction [223,224]. Subsequent similar structures of all BCL-2 family pro-survival proteins in complex with $\mathrm{BH} 3$ domains revealed a common mode of binding whereby the helical pro-apoptotic 
$\mathrm{BH} 3$ domain engaged a long hydrophobic groove containing several small pockets that accommodated hydrophobic moieties projected from the ligand [225-229].

In 2005, the first small-molecule compound, ABT-737, capable of mimicking this interaction was reported [230]. This so-called "BH3-mimetic" drug bound to BCL-2, BCL$\mathrm{XL}$ and BCL-W with low nanomolar affinity and, unlike other putative BCL-2 protein inhibitors described at that time, was able to potently induce mechanism-based (i.e., BAX/BAK-dependent) apoptosis in cell lines, and tumour regression in mouse xenograft models $[230,231]$. Subsequently, an orally bioavailable analogue, ABT-263 ("Navitoclax") was developed with a similar pro-survival protein binding profile [232,233]. Due to its promising preclinical in vivo activity, Navitoclax entered clinical trials though the response rate was relatively low and dose-limiting thrombocytopaenia was observed $[234,235]$. This toxicity was an on-target side-effect of Navitoclax having high affinity for BCL-XL, a critical protein for platelet cell survival [236].

In response to this toxicity, an analogue of Navitoclax, namely ABT-199/Venetoclax that was more specific for BCL-2 was developed [237]. Venetoclax showed significant preclinical activity in BCL-2 driven haematological malignancies in vivo and due to its highly promising results in early phase clinical trials in patients with relapsed or refractory chronic lymphocytic leukaemia, was fast-tracked for approval in the USA, and subsequently approved in other countries for use in a variety of blood cancers, either as a single agent, or combined with other targeted therapies such as Rituximab, where results have been particularly impressive [238]. Trials of Venetoclax with other agents such as chemotherapy (e.g., Azacitidine, Decitabine) are also underway [239,240]. In addition, AstraZenca have developed AZD4320, a dual BCL-2/BCL-XL inhibitor. This is administered intravenously just once per week, and although some thrombocytopaenia is observed, this is transient and platelet levels return to normal within a week of administration [241]. More recently, a dendrimer-conjugated version of AZD4320, AZD0466, was developed resulting in an improved therapeutic index enabling the progression of this optimised candidate into clinical development [242]. Hence, this compound has significant potential for use in BCL-XL-driven cancers.

Following the development of Venetoclax, a number of other pro-survival proteinspecific inhibitors were developed. These include several compounds specific for MCL-1 such as S63845, AZD5991 and AMG 174 [243-245] that show significant efficacy in vitro and in vivo, and some of these are currently undergoing clinical trials. Despite the dependence of platelets on BCL-XL, several potent BCL-XL-specific inhibitors have also been developed including WEHI-539 and A-1331852 [246,247].

The availability of BH3-mimetics targeting most pro-survival proteins (Figure 3) has been enormously useful for studies determining the pro-survival protein dependency of many tumour cell types $[247,248]$. These studies have shown that although some haematological cancers are dependent only on BCL-2 or MCL-1 for their survival, many solid cancers are relatively resistant to most BH3-mimetics as single agents. However, potent killing is achieved when multiple pro-survival proteins are targeted, especially MCL1 and BCL-XL [82,247-251]. Unfortunately, administration of compounds targeting both these proteins (e.g., using $S 63845$ and A-1331852) resulted in acute hepatotoxicity and death in mice [250], although a recent study in melanoma showed MCL-1 and BCL-XL could be targeted with S63845 and ABT-263 if the dosing regimen was carefully controlled [251]. However, it is unclear whether such a strategy would ever be suitable for use in humans due to the potential risks involved. Notably, combinations targeting both MCL-1 and BCL-2 (e.g., S63845 and Venetoclax) have proven efficacious and safe in clinical trials in both haematological (e.g., AML, T-cell ALL, MCL) and solid cancers (e.g., melanoma) [252]. 


\begin{tabular}{|l|l|}
\hline \multicolumn{2}{|c|}{ BH3-mimetics } \\
$\begin{array}{l}\text { Navitoclax } \\
(\text { ABT-263) }\end{array}$ & BCL-2, BCL-XL, BCL-W \\
\hline $\begin{array}{l}\text { AZD4320 } \\
\text { AZD0466 }\end{array}$ & BCL-2, BCL-XL \\
\hline $\begin{array}{l}\text { Venetoclax } \\
\text { (ABT-199) }\end{array}$ & BCL-2 \\
\hline $\begin{array}{l}\text { A-1331852 } \\
\text { WEHI-539 }\end{array}$ & BCL-XL \\
\hline $\begin{array}{l}\text { S63845 } \\
\text { AMG176 } \\
\text { AZD5991 } \\
\text { A-1210477 }\end{array}$ & MCL-1 \\
\hline
\end{tabular}

\begin{tabular}{l|l|}
\multicolumn{2}{|c|}{ BET inhibitors } \\
\hline CC-90010 & BRD2 \\
\hline $\begin{array}{l}\text { CPI-0610 } \\
\text { PLX51107 } \\
\text { ABBV-744 } \\
\text { JQ1 }\end{array}$ & BRD4 \\
\hline GSK2820151 & BRD2/4 \\
\hline $\begin{array}{l}\text { OTX015 } \\
\text { MK-8628 } \\
\text { I-BET151 }\end{array}$ & BRD2/3/4 \\
\hline $\begin{array}{l}\text { ABBV-075 } \\
\text { FT-1101 } \\
\text { GSK525762 } \\
\text { I-BET762 } \\
\text { INCB057643 } \\
\text { ZEN003694 }\end{array}$ & BRD2/3/4, BRDT \\
\hline
\end{tabular}

Figure 3. Examples of BH3-mimetics and their BCL-2 pro-survival proteins targets, and BET inhibitors with their BRD protein targets.

As there are potentially a very large number of solid cancers that could benefit from dual inhibition of MCL-1 and BCL-XL [248], a number of more tumour-specific approaches have been investigated. One way is to combine $\mathrm{BH} 3$-mimetics targeting one of these prosurvival proteins with targeted therapies, such as inhibitors of oncogenic kinases that work by modulating the expression of pro-apoptotic BH3-only proteins. For example, MCL-1 inhibitors (e.g., S63845 or AMG 176) have been combined with inhibitors against MEK, HER2, B-RAF or EGFR and shown to induce a cytotoxic response in solid tumours such as breast, non-small cell lung cancer, lung adenocarcinoma and melanoma cells [243,253]. Perhaps the novel nanoparticle formulation of AZD0466, currently undergoing phase I clinical trials in haematological and solid cancers, will also provide a promising alternate means by which co-administration with an MCL-1 inhibitor can be achieved safely [242]. Another approach that is likely to have far greater specificity for tumour cells is an antibody-drug conjugate whereby A-1331852 is coupled to an antibody specific for cell surface proteins such as the epidermal growth factor (EGF) receptor that are frequently overexpressed in some cancers. Although such compounds have not yet been published, data available from patents suggest these molecules could be highly efficacious, though again it is unclear yet whether they can be safely combined with an MCL-1-specific inhibitor.

In MYC-driven cancers, combinations of BH3-mimetics with drugs that can act on MYC also have potential, and will be discussed below.

\subsection{Drugs Targeting MYC}

MYC is frequently referred to as being 'undruggable' [254]. This is largely a consequence of its mostly disordered structure which lacks well-defined pockets, grooves or other features that are usually targeted by small molecule drugs. Concern has also been raised about the potential unwanted side-effects associated with systemic inhibition of a transcription factor that regulates so many cellular processes. Although there are currently no 'direct' MYC inhibitors used in clinical practice, multiple approaches have been reported that can successfully modulate MYC activity in tumour cells, belying the undruggable label. Strategies that can regulate MYC activity typically fall into two major categories-those that can indirectly influence MYC levels in a cell and those that directly engage MYC or MYC/MAX dimers.

Despite the relatively featureless structure of MYC, a number of compounds have been identified capable of binding to it and inhibiting MYC/MAX dimerisation. Most of the earlier compounds such as IIA6B17, NY2267, 10058-F4 and 10074-G5 [255-258] have relatively low affinity for MYC or MYC/MAX dimers (i.e., $>20 \mu \mathrm{M}$ ), though were capable of inhibiting cell growth in vitro, but with poor pharmacokinetic properties for in vivo application. More potent analogues of 10074-G5 have been developed (JY-3-094, 
3jc48-3) though these have not been proven in vivo. More recently, the compounds Mycro3 and KJ-Pyr-9 were developed with significantly greater in vitro activity and anti-tumour activity in vivo, though none of these have yet to progress into the clinic. In parallel with the development of small molecule inhibitors, a peptidic approach has also been used to inhibit MYC activity. The best example is Omomyc, a mutated miniprotein based on the MYC bHLH-Zip domain $[259,260]$. This acts as a dominant negative protein of MYC and exerts its activity through multiple mechanisms including heterodimerisation with MAX as well as homodimerising which allows it to occupy E-boxes, but not transcribe the target genes due to the lack of the transactivation domain [259-263]. Omomyc has shown impressive anti-tumour activity in a number of transgenic mouse models [264-267] though it also has intrinsic cell-penetrating activity with in vivo activity in lung cancer models when administered via different routes (intranasally or intravenous) [268]. Hence, Omomyc also has significant potential for future clinical development.

A range of compounds that indirectly influence MYC expression in cells have been evaluated. Indeed, some of these have even advanced into early phase clinical trials. These include antisense oligonucleotides that degrade MYC mRNA (e.g., INX-3280) or phosphorodiamidate morpholino oligomers that inhibit MYC protein expression by preventing ribosomal assembly (e.g., AVI-4126/Resten-NG) [269,270]. Trials of both approaches were discontinued for various reasons despite some seemingly positive results. Similarly, siRNA have also been investigated using a range of nanoparticle formulations to improve siRNA stability and delivery [271-275]. Some of these have shown in vivo efficacy in different tumour models and a clinical trial of "DCR-MYC" showed some mechanistic activity, though was abandoned. Major efforts have also gone into development of compounds that can target and stabilise the G-quadraplex structure in the MYC promoter and its transcription. Some of these have been tested in clinical trials, though have also been discontinued [276].

Undoubtedly, the indirect approach to regulating MYC that has gained most attention in recent years is a class of drugs that can target the bromodomains of the bromodomain and extraterminal (BET) proteins BRD2, 3 and 4 (Figure 3). These compounds inhibit association of the BET proteins with acetylated histones on active chromatin, preventing recruitment of transcription factors and, thereby, blocking transcription of target genes, most notably, MYC [277,278]. Since the first BET inhibitor (BETi) JQ1 was reported, a number of other similar compounds have been developed, including some that are specific for particular bromodomains, bivalent BETi and BETi associated with proteolysis-targeting (i.e., PROTACs) moieties [279-284]. The BETi have shown efficacy in a wide range of haematological (e.g., AML, multiple myeloma, ALL) and solid cancers (e.g., NUT midline carcinoma, lung, breast, colon, prostate, brain etc) [285]. Despite evidence for the emergence of a number of resistance mechanisms to BETi [286-288], a number have undergone or are undergoing clinical trials, either as single agents or in combinations, for a large number of cancer types [285]. In general, these drugs have been shown to be tolerated albeit with some toxicities such as thrombocytopaenia and anaemia, though the outcomes from these have been mixed. None have yet to progress beyond trials and been approved for use.

\subsection{Dual Targeting of $M Y C$ and $B C L-2$ Proteins}

Given most cancers have deregulated MYC expression, and as a consequence, BCL-2 pro-survival proteins are often also deregulated to counter the pro-apoptotic effect of high MYC expression, there is a strong rationale for co-targeting of MYC and BCL-2 proteins in many cancers (Figure 2). This strategy to cancer treatment has gained significant momentum in the last five years with the advent of the BETi and BH3-mimetics (Figure 3) which are both suitable for in vivo studies and, moreover, are apparently safe and, in some cases, showing promising activity in patients.

Indeed, a wide range of BETi have now been tested together with various BH3mimetics, though most studies have focussed on Venetoclax where enhanced responses from combining the drugs have been seen in vitro and in vivo in many haematological malignancies including $\mathrm{T}$ cell lymphoma, CLL, T cell acute lymphoblastic leukaemia, 
and diffuse large B cell lymphoma [289-297], and some solid tumours such as small cell lung cancer [298]. The dual BCL-XL/BCL-2 inhibitor Navitoclax was also shown to synergise with BETi in small cell lung cancer, colorectal cancer, glioma and B-cell lymphomas [299-302], whilst BH3-mimetics targeting MCL-1 enhance BETi activity in AML and melanoma [292,303].

Although BETi have the potential to act on multiple cellular pathways, their ability to co-operate with BH3-mimetics is generally associated with their capacity to down-regulate MYC expression. Nevertheless, several distinct mechanisms have been shown to underlie the synergy between BETi and BH3-mimetics. Although, BH3-mimetics act to neutralise any excess pro-survival proteins present within MYC-driven tumours, thereby lowering the threshold for apoptosis induction, the mechanism by which the drugs co-operate is somewhat more complicated. For example, BET inhibition has been shown to suppress miR17-92, a key post-transcriptional repressor of BIM expression [304]. Not surprisingly, BIM upregulation and the resultant increase in the formation of BCL-2/BIM complexes was observed in many studies following BETi treatment [290,292,296,298]. This primes cells to apoptosis, especially that induced by Venetoclax, which can displace any BIM bound to BCL-2 for activation of BAX and BAK [237]. Levels of BCL-2 are also generally decreased following BETi treatment [290,292-294,298,305], though notably, other pro-survival proteins including BCL-XL [292,298], MCL-1 [292] and BFL-1 [295] have been shown to be reduced in different cancer types, leading to a further reduction in the apoptotic threshold of the cell. In colorectal cancer cells, BETi treatment led to repression of MYC-driven expression of miR1271-5p, which in turn led to increased NOXA levels and inhibition of MCL-1, thereby enabling synergy with ABT-263.

\section{Conclusions}

Despite the importance of the connection between deregulated MYC and BCL-2 pro-survival protein expression, and that the mechanisms by which they co-operate in cancer have been known for over two decades, there are still no clinically approved cotreatments that target both proteins. This is largely due to the fact that it has taken many years to develop potent compounds capable of inhibiting BCL-2 pro-survival proteins and MYC. However, recent advances in the development of a number of BH3-mimetics with various specificities, and the success of Venetoclax in patients, means that one arm of this co-operativity can now be effectively disarmed. Although the development of similar directly acting MYC inhibitors has yet to have an impact in the clinic, the BETi that exert much of their activity by downregulation of MYC provide the most promising approach to date to tackle this critical second arm driving many tumours. Most encouraging are the numerous studies described above showing synergy between BETi and BH3-mimetics, including in clinically relevant patient-derived xenograft models [292,293], which showed such combinations are also safe. Nevertheless, there has yet to be a clinical trial examining such combinations. Hence, we expect it is only a matter of time before such combinations are explored in the clinic, with the hope they can provide benefit for the many cancers that depend on the co-operativity between MYC and BCL-2 proteins.

Author Contributions: Writing - original draft preparation, W.D.F. and E.F.L.; writing-review and editing, W.D.F. and E.F.L. All authors have read and agreed to the published version of the manuscript.

Funding: This research was funded by the Victorian Cancer Agency Mid-Career Research Fellowhip, MCRF19045 (to EFL), and the National Health and Medical Research Council of Australia Project Grants, GNT1122829 and GNT1157551 (to WDF).

Institutional Review Board Statement: Not appliable.

Informed Consent Statement: Not appliable.

Data Availability Statement: Not appliable. 
Conflicts of Interest: The authors are former employees of the Walter and Eliza Hall Institute that has previously been involved in collaborations with AbbVie and Genentech to develop and characterise BH3-mimetic drugs. The authors have received payments in respect of Venetoclax. The authors currently collaborate with AstraZeneca on their BH3-mimetic compounds.

\section{References}

1. Youle, R.J.; Strasser, A. The BCL-2 protein family: Opposing activities that mediate cell death. Nat. Rev. Mol. Cell Biol. 2008, 9, 47-59. [CrossRef] [PubMed]

2. Singh, R.; Letai, A.; Sarosiek, K. Regulation of apoptosis in health and disease: The balancing act of BCL-2 family proteins. Nat. Rev. Mol. Cell Biol. 2019, 20, 175-193. [CrossRef]

3. Chen, L.; Willis, S.N.; Wei, A.; Smith, B.J.; Fletcher, J.I.; Hinds, M.G.; Colman, P.M.; Day, C.L.; Adams, J.M.; Huang, D.C. Differential targeting of prosurvival Bcl-2 proteins by their BH3-only ligands allows complementary apoptotic function. Mol. Cell 2005, 17, 393-403. [CrossRef]

4. Willis, S.N.; Fletcher, J.I.; Kaufmann, T.; Van Delft, M.F.; Chen, L.; Czabotar, P.E.; Ierino, H.; Lee, E.F.; Fairlie, W.D.; Bouillet, P.; et al Apoptosis initiated when BH3 ligands engage multiple Bcl-2 homologs, not Bax or Bak. Science 2007, 315, 856-859. [CrossRef]

5. Willis, S.N.; Chen, L.; Dewson, G.; Wei, A.; Naik, E.; Fletcher, J.I.; Adams, J.M.; Huang, D.C. Proapoptotic Bak is sequestered by Mcl-1 and Bcl-xL, but not Bcl-2, until displaced by BH3-only proteins. Genes Dev. 2005, 19, 1294-1305. [CrossRef] [PubMed]

6. Hanahan, D.; Weinberg, R.A. Hallmarks of cancer: The next generation. Cell 2011, 144, 646-674. [CrossRef]

7. Tagawa, H.; Karnan, S.; Suzuki, R.; Matsuo, K.; Zhang, X.; Ota, A.; Morishima, Y.; Nakamura, S.; Seto, M. Genome-wide array-based CGH for mantle cell lymphoma: Identification of homozygous deletions of the proapoptotic gene BIM. Oncogene 2005, 24, 1348-1358. [CrossRef] [PubMed]

8. Tsujimoto, Y.; Finger, L.R.; Yunis, J.; Nowell, P.C.; Croce, C.M. Cloning of the chromosome breakpoint of neoplastic B cells with the $\mathrm{t}(14 ; 18)$ chromosome translocation. Science 1984, 226, 1097-1099. [CrossRef]

9. Vaux, D.L.; Cory, S.; Adams, J.M. Bcl-2 gene promotes haemopoietic cell survival and cooperates with c-myc to immortalize pre-B cells. Nature 1988, 335, 440-442. [CrossRef]

10. Egle, A.; Harris, A.W.; Bouillet, P.; Cory, S. Bim is a suppressor of Myc-induced mouse B cell leukemia. Proc. Natl. Acad. Sci. USA 2004, 101, 6164-6169. [CrossRef]

11. Strasser, A.; Harris, A.W.; Bath, M.L.; Cory, S. Novel primitive lymphoid tumours induced in transgenic mice by cooperation between myc and bcl-2. Nature 1990, 348, 331-333. [CrossRef]

12. Tsujimoto, Y.; Cossman, J.; Jaffe, E.; Croce, C.M. Involvement of the bcl-2 gene in human follicular lymphoma. Science 1985, 228, 14401443. [CrossRef] [PubMed]

13. Tsujimoto, Y.; Croce, C.M. Analysis of the structure, transcripts, and protein products of bcl-2, the gene involved in human follicular lymphoma. Proc. Natl. Acad. Sci. USA 1986, 83, 5214-5218. [CrossRef] [PubMed]

14. Willis, T.G.; Dyer, M.J. The role of immunoglobulin translocations in the pathogenesis of B-cell malignancies. Blood 2000, 96, 808822. [CrossRef] [PubMed]

15. Jonveaux, P.; Hillion, J.; Bennaceur, A.L.; D’Agay, M.F.; Brice, P.; Daniel, M.T.; Sigaux, F.; Berger, R. t(14;18) and bcl-2 gene rearrangement in a B-chronic lymphocytic leukaemia. Br. J. Haematol. 1992, 81, 620-621. [CrossRef] [PubMed]

16. Tashiro, S.; Takechi, M.; Asou, H.; Takauchi, K.; Kyo, T.; Dohy, H.; Kikuchi, M.; Kamada, N.; Tsujimoto, Y. Cytogenetic 2; 18 and $18 ; 22$ translocation in chronic lymphocytic leukemia with juxtaposition of bcl-2 and immunoglobulin light chain genes. Oncogene 1992, 7, 573-577. [PubMed]

17. Bakhshi, A.; Jensen, J.P.; Goldman, P.; Wright, J.J.; McBride, O.W.; Epstein, A.L.; Korsmeyer, S.J. Cloning the chromosomal breakpoint of $\mathrm{t}(14 ; 18)$ human lymphomas: Clustering around $\mathrm{JH}$ on chromosome 14 and near a transcriptional unit on 18 . Cell 1985, 41, 899-906. [CrossRef]

18. Cleary, M.L.; Sklar, J. Nucleotide sequence of a t(14;18) chromosomal breakpoint in follicular lymphoma and demonstration of a breakpoint-cluster region near a transcriptionally active locus on chromosome 18. Proc. Natl. Acad. Sci. USA 1985, 82, 7439-7443. [CrossRef]

19. Cleary, M.L.; Smith, S.D.; Sklar, J. Cloning and structural analysis of cDNAs for bcl-2 and a hybrid bcl-2/immunoglobulin transcript resulting from the $\mathrm{t}(14 ; 18)$ translocation. Cell 1986, 47, 19-28. [CrossRef]

20. Dyer, M.J.; Zani, V.J.; Lu, W.Z.; O’Byrne, A.; Mould, S.; Chapman, R.; Heward, J.M.; Kayano, H.; Jadayel, D.; Matutes, E.; et al. BCL2 translocations in leukemias of mature B cells. Blood 1994, 83, 3682-3688. [CrossRef]

21. Gascoyne, R.D.; Adomat, S.A.; Krajewski, S.; Krajewska, M.; Horsman, D.E.; Tolcher, A.W.; O’Reilly, S.E.; Hoskins, P.; Coldman, A.J.; Reed, J.C.; et al. Prognostic significance of Bcl-2 protein expression and Bcl-2 gene rearrangement in diffuse aggressive non-Hodgkin's lymphoma. Blood 1997, 90, 244-251. [CrossRef]

22. Hill, M.E.; MacLennan, K.A.; Cunningham, D.C.; Vaughan Hudson, B.; Burke, M.; Clarke, P.; Di Stefano, F.; Anderson, L.; Vaughan Hudson, G.; Mason, D.; et al. Prognostic significance of BCL-2 expression and bcl-2 major breakpoint region rearrangement in diffuse large cell non-Hodgkin's lymphoma: A British National Lymphoma Investigation Study. Blood 1996, 88, $1046-1051$. [CrossRef]

23. Skinnider, B.F.; Horsman, D.E.; Dupuis, B.; Gascoyne, R.D. Bcl-6 and Bcl-2 protein expression in diffuse large B-cell lymphoma and follicular lymphoma: Correlation with 3q27 and 18q21 chromosomal abnormalities. Hum. Pathol. 1999, 30, 803-808. [CrossRef] 
24. Hanada, M.; Delia, D.; Aiello, A.; Stadtmauer, E.; Reed, J.C. bcl-2 gene hypomethylation and high-level expression in B-cell chronic lymphocytic leukemia. Blood 1993, 82, 1820-1828. [CrossRef]

25. Zutter, M.; Hockenbery, D.; Silverman, G.A.; Korsmeyer, S.J. Immunolocalization of the Bcl-2 protein within hematopoietic neoplasms. Blood 1991, 78, 1062-1068. [CrossRef] [PubMed]

26. Monni, O.; Joensuu, H.; Franssila, K.; Klefstrom, J.; Alitalo, K.; Knuutila, S. BCL2 overexpression associated with chromosomal amplification in diffuse large B-cell lymphoma. Blood 1997, 90, 1168-1174. [CrossRef] [PubMed]

27. Punnoose, E.A.; Leverson, J.D.; Peale, F.; Boghaert, E.R.; Belmont, L.D.; Tan, N.; Young, A.; Mitten, M.; Ingalla, E.; Darbonne, W.C.; et al. Expression Profile of BCL-2, BCL-XL, and MCL-1 Predicts Pharmacological Response to the BCL-2 Selective Antagonist Venetoclax in Multiple Myeloma Models. Mol. Cancer Ther. 2016, 15, 1132-1144. [CrossRef] [PubMed]

28. Agarwal, B.; Naresh, K.N. Bcl-2 family of proteins in indolent B-cell non-Hodgkin's lymphoma: Study of 116 cases. Am. J. Hematol. 2002, 70, 278-282. [CrossRef] [PubMed]

29. Saito, M.; Novak, U.; Piovan, E.; Basso, K.; Sumazin, P.; Schneider, C.; Crespo, M.; Shen, Q.; Bhagat, G.; Califano, A.; et al. BCL6 suppression of BCL2 via Miz1 and its disruption in diffuse large B cell lymphoma. Proc. Natl. Acad. Sci. USA 2009, 106, 11294-11299. [CrossRef]

30. Avet-Loiseau, H.; Li, J.Y.; Morineau, N.; Facon, T.; Brigaudeau, C.; Harousseau, J.L.; Grosbois, B.; Bataille, R. Monosomy 13 is associated with the transition of monoclonal gammopathy of undetermined significance to multiple myeloma. Intergroupe Francophone du Myelome. Blood 1999, 94, 2583-2589. [CrossRef]

31. Calin, G.A.; Ferracin, M.; Cimmino, A.; Di Leva, G.; Shimizu, M.; Wojcik, S.E.; Iorio, M.V.; Visone, R.; Sever, N.I.; Fabbri, M.; et al. A MicroRNA signature associated with prognosis and progression in chronic lymphocytic leukemia. N. Engl. J. Med. 2005, 353, 1793-1801. [CrossRef]

32. Cimmino, A.; Calin, G.A.; Fabbri, M.; Iorio, M.V.; Ferracin, M.; Shimizu, M.; Wojcik, S.E.; Aqeilan, R.I.; Zupo, S.; Dono, M.; et al. miR-15 and miR-16 induce apoptosis by targeting BCL2. Proc. Natl. Acad. Sci. USA 2005, 102, 13944-13949. [CrossRef] [PubMed]

33. Gatt, M.E.; Zhao, J.J.; Ebert, M.S.; Zhang, Y.; Chu, Z.; Mani, M.; Gazit, R.; Carrasco, D.E.; Dutta-Simmons, J.; Adamia, S.; et al. MicroRNAs 15a/16-1 function as tumor suppressor genes in multiple myeloma. Blood 2010. [CrossRef] [PubMed]

34. Iqbal, J.; Neppalli, V.T.; Wright, G.; Dave, B.J.; Horsman, D.E.; Rosenwald, A.; Lynch, J.; Hans, C.P.; Weisenburger, D.D.; Greiner, T.C.; et al. BCL2 expression is a prognostic marker for the activated B-cell-like type of diffuse large B-cell lymphoma. J. Clin. Oncol. 2006, 24, 961-968. [CrossRef]

35. Pezzella, F.; Turley, H.; Kuzu, I.; Tungekar, M.F.; Dunnill, M.S.; Pierce, C.B.; Harris, A.; Gatter, K.C.; Mason, D.Y. bcl-2 protein in non-small-cell lung carcinoma. N. Engl. J. Med. 1993, 329, 690-694. [CrossRef]

36. Colombel, M.; Symmans, F.; Gil, S.; O’Toole, K.M.; Chopin, D.; Benson, M.; Olsson, C.A.; Korsmeyer, S.; Buttyan, R. Detection of the apoptosis-suppressing oncoprotein bc1-2 in hormone-refractory human prostate cancers. Am. J. Pathol. 1993, 143, 390-400.

37. Charlotte, F.; L'Hermine, A.; Martin, N.; Geleyn, Y.; Nollet, M.; Gaulard, P.; Zafrani, E.S. Immunohistochemical detection of bcl-2 protein in normal and pathological human liver. Am. J. Pathol. 1994, 144, 460-465.

38. Merino, D.; Lok, S.W.; Visvader, J.E.; Lindeman, G.J. Targeting BCL-2 to enhance vulnerability to therapy in estrogen receptorpositive breast cancer. Oncogene 2016, 35, 1877-1887. [CrossRef]

39. Hermine, O.; Haioun, C.; Lepage, E.; D’Agay, M.F.; Briere, J.; Lavignac, C.; Fillet, G.; Salles, G.; Marolleau, J.P.; Diebold, J.; et al. Prognostic significance of bcl-2 protein expression in aggressive non-Hodgkin's lymphoma. Groupe d'Etude des Lymphomes de l'Adulte (GELA). Blood 1996, 87, 265-272. [CrossRef] [PubMed]

40. McDonnell, T.J.; Troncoso, P.; Brisbay, S.M.; Logothetis, C.; Chung, L.W.; Hsieh, J.T.; Tu, S.M.; Campbell, M.L. Expression of the protooncogene bcl-2 in the prostate and its association with emergence of androgen-independent prostate cancer. Cancer Res. 1992, 52, 6940-6944. [PubMed]

41. Robertson, L.E.; Plunkett, W.; McConnell, K.; Keating, M.J.; McDonnell, T.J. Bcl-2 expression in chronic lymphocytic leukemia and its correlation with the induction of apoptosis and clinical outcome. Leukemia 1996, 10, 456-459. [PubMed]

42. Campos, L.; Rouault, J.P.; Sabido, O.; Oriol, P.; Roubi, N.; Vasselon, C.; Archimbaud, E.; Magaud, J.P.; Guyotat, D. High expression of bcl-2 protein in acute myeloid leukemia cells is associated with poor response to chemotherapy. Blood 1993, 81, 3091-3096. [CrossRef]

43. Miyashita, T.; Reed, J.C. bcl-2 gene transfer increases relative resistance of S49.1 and WEHI7.2 lymphoid cells to cell death and DNA fragmentation induced by glucocorticoids and multiple chemotherapeutic drugs. Cancer Res. 1992, 52, 5407-5411.

44. Miyashita, T.; Reed, J.C. Bcl-2 oncoprotein blocks chemotherapy-induced apoptosis in a human leukemia cell line. Blood 1993, 81, 151-157. [CrossRef] [PubMed]

45. Piris, M.A.; Pezzella, F.; Martinez-Montero, J.C.; Orradre, J.L.; Villuendas, R.; Sanchez-Beato, M.; Cuena, R.; Cruz, M.A.; Martinez, B.; Pezella, F.; et al. p53 and bcl-2 expression in high-grade B-cell lymphomas: Correlation with survival time. Br. J. Cancer 1994, 69, 337-341. [CrossRef]

46. Tang, S.C.; Visser, L.; Hepperle, B.; Hanson, J.; Poppema, S. Clinical significance of bcl-2-MBR gene rearrangement and protein expression in diffuse large-cell non-Hodgkin's lymphoma: An analysis of 83 cases. J. Clin. Oncol. 1994, 12, 149-154. [CrossRef] [PubMed]

47. Casado, S.; Forteza, J.; Dominguez, S.; Abad, M.T.; Perez, I.; Intxaurbe, I.; Del Campo, J.M.; Lopez, R. Predictive value of P53, BCL-2, and BAX in advanced head and neck carcinoma. Am. J. Clin. Oncol. 2002, 25, 588-590. [CrossRef] 
48. Stavropoulos, N.E.; Filiadis, I.; Ioachim, E.; Hastazeris, K.; Tsimaris, I.; Kalogeras, D.; Stefanaki, S.; Agnantis, N.J. Prognostic significance of p53, bcl-2 and Ki-67 in high risk superficial bladder cancer. Anticancer Res. 2002, 22, 3759-3764.

49. Callagy, G.M.; Webber, M.J.; Pharoah, P.D.; Caldas, C. Meta-analysis confirms BCL2 is an independent prognostic marker in breast cancer. BMC Cancer 2008, 8, 153. [CrossRef] [PubMed]

50. Dawson, S.J.; Makretsov, N.; Blows, F.M.; Driver, K.E.; Provenzano, E.; Le Quesne, J.; Baglietto, L.; Severi, G.; Giles, G.G.; McLean, C.A.; et al. BCL2 in breast cancer: A favourable prognostic marker across molecular subtypes and independent of adjuvant therapy received. Br. J. Cancer 2010, 103, 668-675. [CrossRef] [PubMed]

51. Beroukhim, R.; Mermel, C.H.; Porter, D.; Wei, G.; Raychaudhuri, S.; Donovan, J.; Barretina, J.; Boehm, J.S.; Dobson, J.; Urashima, M.; et al. The landscape of somatic copy-number alteration across human cancers. Nature 2010, 463, 899-905. [CrossRef]

52. Kozopas, K.M.; Yang, T.; Buchan, H.L.; Zhou, P.; Craig, R.W. MCL1, a gene expressed in programmed myeloid cell differentiation, has sequence similarity to BCL2. Proc. Natl. Acad. Sci. USA 1993, 90, 3516-3520. [CrossRef]

53. Kendall, J.; Liu, Q.; Bakleh, A.; Krasnitz, A.; Nguyen, K.C.; Lakshmi, B.; Gerald, W.L.; Powers, S.; Mu, D. Oncogenic cooperation and coamplification of developmental transcription factor genes in lung cancer. Proc. Natl. Acad. Sci. USA 2007, 104, 16663-16668. [CrossRef]

54. Weir, B.A.; Woo, M.S.; Getz, G.; Perner, S.; Ding, L.; Beroukhim, R.; Lin, W.M.; Province, M.A.; Kraja, A.; Johnson, L.A.; et al. Characterizing the cancer genome in lung adenocarcinoma. Nature 2007, 450, 893-898. [CrossRef] [PubMed]

55. Lin, W.M.; Baker, A.C.; Beroukhim, R.; Winckler, W.; Feng, W.; Marmion, J.M.; Laine, E.; Greulich, H.; Tseng, H.; Gates, C.; et al. Modeling genomic diversity and tumor dependency in malignant melanoma. Cancer Res. 2008, 68, 664-673. [CrossRef] [PubMed]

56. Mott, J.L.; Kobayashi, S.; Bronk, S.F.; Gores, G.J. mir-29 regulates Mcl-1 protein expression and apoptosis. Oncogene 2007, 26, 6133-6140. [CrossRef] [PubMed]

57. Kobayashi, S.; Werneburg, N.W.; Bronk, S.F.; Kaufmann, S.H.; Gores, G.J. Interleukin-6 contributes to Mcl-1 up-regulation and TRAIL resistance via an Akt-signaling pathway in cholangiocarcinoma cells. Gastroenterology 2005, 128, 2054-2065. [CrossRef]

58. Le Gouill, S.; Podar, K.; Amiot, M.; Hideshima, T.; Chauhan, D.; Ishitsuka, K.; Kumar, S.; Raje, N.; Richardson, P.G.; Harousseau, J.L.; et al. VEGF induces Mcl-1 up-regulation and protects multiple myeloma cells against apoptosis. Blood 2004, 104, 2886-2892. [CrossRef] [PubMed]

59. Hussain, S.R.; Cheney, C.M.; Johnson, A.J.; Lin, T.S.; Grever, M.R.; Caligiuri, M.A.; Lucas, D.M.; Byrd, J.C. Mcl-1 is a relevant therapeutic target in acute and chronic lymphoid malignancies: Down-regulation enhances rituximab-mediated apoptosis and complement-dependent cytotoxicity. Clin. Cancer Res. 2007, 13, 2144-2150. [CrossRef]

60. Kitada, S.; Andersen, J.; Akar, S.; Zapata, J.M.; Takayama, S.; Krajewski, S.; Wang, H.G.; Zhang, X.; Bullrich, F.; Croce, C.M.; et al. Expression of apoptosis-regulating proteins in chronic lymphocytic leukemia: Correlations with In vitro and In vivo chemoresponses. Blood 1998, 91, 3379-3389. [CrossRef]

61. Pedersen, I.M.; Kitada, S.; Leoni, L.M.; Zapata, J.M.; Karras, J.G.; Tsukada, N.; Kipps, T.J.; Choi, Y.S.; Bennett, F.; Reed, J.C. Protection of CLL B cells by a follicular dendritic cell line is dependent on induction of Mcl-1. Blood 2002, 100, $1795-1801$. [CrossRef]

62. Cho-Vega, J.H.; Rassidakis, G.Z.; Admirand, J.H.; Oyarzo, M.; Ramalingam, P.; Paraguya, A.; McDonnell, T.J.; Amin, H.M.; Medeiros, L.J. MCL-1 expression in B-cell non-Hodgkin's lymphomas. Hum. Pathol. 2004, 35, 1095-1100. [CrossRef] [PubMed]

63. Tonon, G.; Wong, K.K.; Maulik, G.; Brennan, C.; Feng, B.; Zhang, Y.; Khatry, D.B.; Protopopov, A.; You, M.J.; Aguirre, A.J.; et al. High-resolution genomic profiles of human lung cancer. Proc. Natl. Acad. Sci. USA 2005, 102, 9625-9630. [CrossRef]

64. Smith, L.T.; Mayerson, J.; Nowak, N.J.; Suster, D.; Mohammed, N.; Long, S.; Auer, H.; Jones, S.; McKeegan, C.; Young, G.; et al. 20q11.1 amplification in giant-cell tumor of bone: Array CGH, FISH, and association with outcome. Genes Chromosomes Cancer 2006, 45, 957-966. [CrossRef]

65. Lefort, N.; Feyeux, M.; Bas, C.; Feraud, O.; Bennaceur-Griscelli, A.; Tachdjian, G.; Peschanski, M.; Perrier, A.L. Human embryonic stem cells reveal recurrent genomic instability at 20q11.21. Nat. Biotechnol. 2008, 26, 1364-1366. [CrossRef] [PubMed]

66. Spits, C.; Mateizel, I.; Geens, M.; Mertzanidou, A.; Staessen, C.; Vandeskelde, Y.; Van der Elst, J.; Liebaers, I.; Sermon, K. Recurrent chromosomal abnormalities in human embryonic stem cells. Nat. Biotechnol. 2008, 26, 1361-1363. [CrossRef] [PubMed]

67. Tu, Y.; Renner, S.; Xu, F.; Fleishman, A.; Taylor, J.; Weisz, J.; Vescio, R.; Rettig, M.; Berenson, J.; Krajewski, S.; et al. BCL-X expression in multiple myeloma: Possible indicator of chemoresistance. Cancer Res. 1998, 58, 256-262. [PubMed]

68. Peeters, S.D.; Hovenga, S.; Rosati, S.; Vellenga, E. Bcl-xl expression in multiple myeloma. Med. Oncol. 2005, 22, 183-190. [CrossRef]

69. Horita, M.; Andreu, E.J.; Benito, A.; Arbona, C.; Sanz, C.; Benet, I.; Prosper, F.; Fernandez-Luna, J.L. Blockade of the Bcr-Abl kinase activity induces apoptosis of chronic myelogenous leukemia cells by suppressing signal transducer and activator of transcription 5-dependent expression of Bcl-xL. J. Exp. Med. 2000, 191, 977-984. [CrossRef] [PubMed]

70. Cerami, E.; Gao, J.; Dogrusoz, U.; Gross, B.E.; Sumer, S.O.; Aksoy, B.A.; Jacobsen, A.; Byrne, C.J.; Heuer, M.L.; Larsson, E.; et al. The cBio cancer genomics portal: An open platform for exploring multidimensional cancer genomics data. Cancer Discov. 2012, 2, 401-404. [CrossRef]

71. Zhang, H.; Xue, J.; Hessler, P.; Tahir, S.K.; Chen, J.; Jin, S.; Souers, A.J.; Leverson, J.D.; Lam, L.T. Genomic analysis and selective small molecule inhibition identifies BCL-X(L) as a critical survival factor in a subset of colorectal cancer. Mol. Cancer 2015, 14, 126. [CrossRef] [PubMed]

72. Scherr, A.L.; Gdynia, G.; Salou, M.; Radhakrishnan, P.; Duglova, K.; Heller, A.; Keim, S.; Kautz, N.; Jassowicz, A.; Elssner, C.; et al. $\mathrm{Bcl}-\mathrm{xL}$ is an oncogenic driver in colorectal cancer. Cell Death Dis. 2016, 7, e2342. [CrossRef] 
73. Feuerhake, F.; Kutok, J.L.; Monti, S.; Chen, W.; LaCasce, A.S.; Cattoretti, G.; Kurtin, P.; Pinkus, G.S.; De Leval, L.; Harris, N.L.; et al. NFkappaB activity, function, and target-gene signatures in primary mediastinal large B-cell lymphoma and diffuse large B-cell lymphoma subtypes. Blood 2005, 106, 1392-1399. [CrossRef]

74. Morales, A.A.; Olsson, A.; Celsing, F.; Osterborg, A.; Jondal, M.; Osorio, L.M. High expression of bfl-1 contributes to the apoptosis resistant phenotype in B-cell chronic lymphocytic leukemia. Int. J. Cancer 2005, 113, 730-737. [CrossRef]

75. Nagy, B.; Lundan, T.; Larramendy, M.L.; Aalto, Y.; Zhu, Y.; Niini, T.; Edgren, H.; Ferrer, A.; Vilpo, J.; Elonen, E.; et al. Abnormal expression of apoptosis-related genes in haematological malignancies: Overexpression of MYC is poor prognostic sign in mantle cell lymphoma. Br. J. Haematol. 2003, 120, 434-441. [CrossRef] [PubMed]

76. Olsson, A.; Norberg, M.; Okvist, A.; Derkow, K.; Choudhury, A.; Tobin, G.; Celsing, F.; Osterborg, A.; Rosenquist, R.; Jondal, M.; et al. Upregulation of bfl-1 is a potential mechanism of chemoresistance in B-cell chronic lymphocytic leukaemia. Br. J. Cancer 2007, 97, 769-777. [CrossRef]

77. Park, I.C.; Lee, S.H.; Whang, D.Y.; Hong, W.S.; Choi, S.S.; Shin, H.S.; Choe, T.B.; Hong, S.I. Expression of a novel Bcl-2 related gene, Bfl-1, in various human cancers and cancer cell lines. Anticancer Res. 1997, 17, 4619-4622.

78. Beverly, L.J.; Varmus, H.E. MYC-induced myeloid leukemogenesis is accelerated by all six members of the antiapoptotic BCL family. Oncogene 2009, 28, 1274-1279. [CrossRef] [PubMed]

79. Yoon, H.S.; Hong, S.H.; Kang, H.J.; Ko, B.K.; Ahn, S.H.; Huh, J.R. Bfl-1 gene expression in breast cancer: Its relationship with other prognostic factors. J. Korean Med. Sci. 2003, 18, 225-230. [CrossRef] [PubMed]

80. Haq, R.; Yokoyama, S.; Hawryluk, E.B.; Jonsson, G.B.; Frederick, D.T.; McHenry, K.; Porter, D.; Tran, T.N.; Love, K.T.; Langer, R.; et al. BCL2A1 is a lineage-specific antiapoptotic melanoma oncogene that confers resistance to BRAF inhibition. Proc. Natl. Acad. Sci. USA 2013, 110, 4321-4326. [CrossRef]

81. Hind, C.K.; Carter, M.J.; Harris, C.L.; Chan, H.T.; James, S.; Cragg, M.S. Role of the pro-survival molecule Bfl-1 in melanoma. Int. J. Biochem. Cell Biol. 2015, 59, 94-102. [CrossRef] [PubMed]

82. Lee, E.F.; Harris, T.J.; Tran, S.; Evangelista, M.; Arulananda, S.; John, T.; Ramnac, C.; Hobbs, C.; Zhu, H.; Gunasingh, G.; et al. BCL-XL and MCL-1 are the key BCL-2 family proteins in melanoma cell survival. Cell Death Dis. 2019, 10, 342. [CrossRef]

83. Lucas, K.M.; Mohana-Kumaran, N.; Lau, D.; Zhang, X.D.; Hersey, P.; Huang, D.C.; Weninger, W.; Haass, N.K.; Allen, J.D. Modulation of NOXA and MCL-1 as a strategy for sensitizing melanoma cells to the BH3-mimetic ABT-737. Clin. Cancer Res. 2012, 18, 783-795. [CrossRef] [PubMed]

84. Placzek, W.J.; Wei, J.; Kitada, S.; Zhai, D.; Reed, J.C.; Pellecchia, M. A survey of the anti-apoptotic Bcl-2 subfamily expression in cancer types provides a platform to predict the efficacy of Bcl-2 antagonists in cancer therapy. Cell Death Dis. 2010, 1, e40. [CrossRef] [PubMed]

85. Senft, D.; Berking, C.; Graf, S.A.; Kammerbauer, C.; Ruzicka, T.; Besch, R. Selective induction of cell death in melanoma cell lines through targeting of Mcl-1 and A1. PLoS ONE 2012, 7, e30821. [CrossRef]

86. Adams, C.M.; Kim, A.S.; Mitra, R.; Choi, J.K.; Gong, J.Z.; Eischen, C.M. BCL-W has a fundamental role in B cell survival and lymphomagenesis. J. Clin. Investig. 2017, 127, 635-650. [CrossRef] [PubMed]

87. Adams, C.M.; Mitra, R.; Gong, J.Z.; Eischen, C.M. Non-Hodgkin and Hodgkin Lymphomas Select for Overexpression of BCLW. Clin. Cancer Res. 2017, 23, 7119-7129. [CrossRef] [PubMed]

88. Adams, C.M.; Mitra, R.; Vogel, A.N.; Liu, J.; Gong, J.Z.; Eischen, C.M. Targeting BCL-W and BCL-XL as a therapeutic strategy for Hodgkin lymphoma. Leukemia 2020, 34, 947-952. [CrossRef]

89. Bandres, E.; Cubedo, E.; Agirre, X.; Malumbres, R.; Zarate, R.; Ramirez, N.; Abajo, A.; Navarro, A.; Moreno, I.; Monzo, M.; et al. Identification by Real-time PCR of 13 mature microRNAs differentially expressed in colorectal cancer and non-tumoral tissues. Mol. Cancer 2006, 5, 29. [CrossRef]

90. Chen, X.N.; Wang, K.F.; Xu, Z.Q.; Li, S.J.; Liu, Q.; Fu, D.H.; Wang, X.; Wu, B. MiR-133b regulates bladder cancer cell proliferation and apoptosis by targeting Bcl-w and Akt1. Cancer Cell Int. 2014, 14, 70. [CrossRef]

91. Crawford, M.; Batte, K.; Yu, L.; Wu, X.; Nuovo, G.J.; Marsh, C.B.; Otterson, G.A.; Nana-Sinkam, S.P. MicroRNA 133B targets pro-survival molecules MCL-1 and BCL2L2 in lung cancer. Biochem. Biophys. Res. Commun. 2009, 388, 483-489. [CrossRef]

92. Kondo, S.; Shinomura, Y.; Miyazaki, Y.; Kiyohara, T.; Tsutsui, S.; Kitamura, S.; Nagasawa, Y.; Nakahara, M.; Kanayama, S.; Matsuzawa, Y. Mutations of the bak gene in human gastric and colorectal cancers. Cancer Res. 2000, 60, 4328-4330.

93. Meijerink, J.P.; Mensink, E.J.; Wang, K.; Sedlak, T.W.; Sloetjes, A.W.; De Witte, T.; Waksman, G.; Korsmeyer, S.J. Hematopoietic malignancies demonstrate loss-of-function mutations of BAX. Blood 1998, 91, 2991-2997. [CrossRef]

94. Yagi, O.K.; Akiyama, Y.; Nomizu, T.; Iwama, T.; Endo, M.; Yuasa, Y. Proapoptotic gene BAX is frequently mutated in hereditary nonpolyposis colorectal cancers but not in adenomas. Gastroenterology 1998, 114, 268-274. [CrossRef]

95. Mestre-Escorihuela, C.; Rubio-Moscardo, F.; Richter, J.A.; Siebert, R.; Climent, J.; Fresquet, V.; Beltran, E.; Agirre, X.; Marugan, I.; Marin, M.; et al. Homozygous deletions localize novel tumor suppressor genes in B-cell lymphomas. Blood 2007, 109, 271-280. [CrossRef] [PubMed]

96. Richter-Larrea, J.A.; Robles, E.F.; Fresquet, V.; Beltran, E.; Rullan, A.J.; Agirre, X.; Calasanz, M.J.; Panizo, C.; Richter, J.A.; Hernandez, J.M.; et al. Reversion of epigenetically mediated BIM silencing overcomes chemoresistance in Burkitt lymphoma. Blood 2010, 116, 2531-2542. [CrossRef] [PubMed]

97. Roussel, M.; Saule, S.; Lagrou, C.; Rommens, C.; Beug, H.; Graf, T.; Stehelin, D. Three new types of viral oncogene of cellular origin specific for haematopoietic cell transformation. Nature 1979, 281, 452-455. [CrossRef] [PubMed] 
98. Sheiness, D.; Bishop, J.M. DNA and RNA from uninfected vertebrate cells contain nucleotide sequences related to the putative transforming gene of avian myelocytomatosis virus. J. Virol. 1979, 31, 514-521. [CrossRef] [PubMed]

99. Reddy, E.P.; Reynolds, R.K.; Watson, D.K.; Schultz, R.A.; Lautenberger, J.; Papas, T.S. Nucleotide sequence analysis of the proviral genome of avian myelocytomatosis virus (MC29). Proc. Natl. Acad. Sci. USA 1983, 80, 2500-2504. [CrossRef] [PubMed]

100. Lee, C.M.; Reddy, E.P. The v-myc oncogene. Oncogene 1999, 18, 2997-3003. [CrossRef]

101. Blackwell, T.K.; Kretzner, L.; Blackwood, E.M.; Eisenman, R.N.; Weintraub, H. Sequence-specific DNA binding by the c-Myc protein. Science 1990, 250, 1149-1151. [CrossRef]

102. Blackwood, E.M.; Eisenman, R.N. Max: A helix-loop-helix zipper protein that forms a sequence-specific DNA-binding complex with Myc. Science 1991, 251, 1211-1217. [CrossRef] [PubMed]

103. Nair, S.K.; Burley, S.K. X-ray structures of Myc-Max and Mad-Max recognizing DNA. Molecular bases of regulation by protooncogenic transcription factors. Cell 2003, 112, 193-205. [CrossRef]

104. Zeller, K.I.; Zhao, X.; Lee, C.W.; Chiu, K.P.; Yao, F.; Yustein, J.T.; Ooi, H.S.; Orlov, Y.L.; Shahab, A.; Yong, H.C.; et al. Global mapping of c-Myc binding sites and target gene networks in human B cells. Proc. Natl. Acad. Sci. USA 2006, 103, 17834-17839. [CrossRef]

105. Fernandez, P.C.; Frank, S.R.; Wang, L.; Schroeder, M.; Liu, S.; Greene, J.; Cocito, A.; Amati, B. Genomic targets of the human c-Myc protein. Genes Dev. 2003, 17, 1115-1129. [CrossRef] [PubMed]

106. Baluapuri, A.; Wolf, E.; Eilers, M. Target gene-independent functions of MYC oncoproteins. Nat. Rev. Mol. Cell Biol. 2020, $21,255-267$. [CrossRef]

107. Menssen, A.; Hermeking, H. Characterization of the c-MYC-regulated transcriptome by SAGE: Identification and analysis of c-MYC target genes. Proc. Natl. Acad. Sci. USA 2002, 99, 6274-6279. [CrossRef] [PubMed]

108. Li, Z.; Van Calcar, S.; Qu, C.; Cavenee, W.K.; Zhang, M.Q.; Ren, B. A global transcriptional regulatory role for c-Myc in Burkitt's lymphoma cells. Proc. Natl. Acad. Sci. USA 2003, 100, 8164-8169. [CrossRef] [PubMed]

109. Kim, J.; Lee, J.H.; Iyer, V.R. Global identification of Myc target genes reveals its direct role in mitochondrial biogenesis and its E-box usage in vivo. PLOS ONE 2008, 3, e1798. [CrossRef]

110. Seitz, V.; Butzhammer, P.; Hirsch, B.; Hecht, J.; Gutgemann, I.; Ehlers, A.; Lenze, D.; Oker, E.; Sommerfeld, A.; Von der Wall, E.; et al. Deep sequencing of MYC DNA-binding sites in Burkitt lymphoma. PLoS ONE 2011, 6, e26837. [CrossRef]

111. Nie, Z.; Hu, G.; Wei, G.; Cui, K.; Yamane, A.; Resch, W.; Wang, R.; Green, D.R.; Tessarollo, L.; Casellas, R.; et al. c-Myc is a universal amplifier of expressed genes in lymphocytes and embryonic stem cells. Cell 2012, 151, 68-79. [CrossRef]

112. Lin, C.Y.; Loven, J.; Rahl, P.B.; Paranal, R.M.; Burge, C.B.; Bradner, J.E.; Lee, T.I.; Young, R.A. Transcriptional amplification in tumor cells with elevated c-Myc. Cell 2012, 151, 56-67. [CrossRef]

113. Waters, C.M.; Littlewood, T.D.; Hancock, D.C.; Moore, J.P.; Evan, G.I. c-myc protein expression in untransformed fibroblasts. Oncogene 1991, 6, 797-805. [PubMed]

114. Kelly, K.; Cochran, B.H.; Stiles, C.D.; Leder, P. Cell-specific regulation of the c-myc gene by lymphocyte mitogens and plateletderived growth factor. Cell 1983, 35, 603-610. [CrossRef]

115. He, T.C.; Sparks, A.B.; Rago, C.; Hermeking, H.; Zawel, L.; Da Costa, L.T.; Morin, P.J.; Vogelstein, B.; Kinzler, K.W. Identification of c-MYC as a target of the APC pathway. Science 1998, 281, 1509-1512. [CrossRef]

116. Zhu, J.; Blenis, J.; Yuan, J. Activation of PI3K/Akt and MAPK pathways regulates Myc-mediated transcription by phosphorylating and promoting the degradation of Mad1. Proc. Natl. Acad. Sci. USA 2008, 105, 6584-6589. [CrossRef] [PubMed]

117. Sander, S.; Calado, D.P.; Srinivasan, L.; Kochert, K.; Zhang, B.; Rosolowski, M.; Rodig, S.J.; Holzmann, K.; Stilgenbauer, S.; Siebert, R.; et al. Synergy between PI3K signaling and MYC in Burkitt lymphomagenesis. Cancer Cell 2012, 22, 167-179. [CrossRef] [PubMed]

118. Sears, R.; Nuckolls, F.; Haura, E.; Taya, Y.; Tamai, K.; Nevins, J.R. Multiple Ras-dependent phosphorylation pathways regulate Myc protein stability. Genes Dev. 2000, 14, 2501-2514. [CrossRef]

119. Weng, A.P.; Millholland, J.M.; Yashiro-Ohtani, Y.; Arcangeli, M.L.; Lau, A.; Wai, C.; Del Bianco, C.; Rodriguez, C.G.; Sai, H.; Tobias, J.; et al. c-Myc is an important direct target of Notch1 in T-cell acute lymphoblastic leukemia/lymphoma. Genes Dev. 2006, 20, $2096-2109$. [CrossRef]

120. Gomez-Roman, N.; Felton-Edkins, Z.A.; Kenneth, N.S.; Goodfellow, S.J.; Athineos, D.; Zhang, J.; Ramsbottom, B.A.; Innes, F.; Kantidakis, T.; Kerr, E.R.; et al. Activation by c-Myc of transcription by RNA polymerases I, II and III. Biochem. Soc. Symp. 2006, 141-154. [CrossRef]

121. Grandori, C.; Gomez-Roman, N.; Felton-Edkins, Z.A.; Ngouenet, C.; Galloway, D.A.; Eisenman, R.N.; White, R.J. c-Myc binds to human ribosomal DNA and stimulates transcription of rRNA genes by RNA polymerase I. Nat. Cell Biol. 2005, 7, 311-318. [CrossRef] [PubMed]

122. Gomez-Roman, N.; Grandori, C.; Eisenman, R.N.; White, R.J. Direct activation of RNA polymerase III transcription by c-Myc. Nature 2003, 421, 290-294. [CrossRef] [PubMed]

123. Hayward, W.S.; Neel, B.G.; Astrin, S.M. Activation of a cellular onc gene by promoter insertion in ALV-induced lymphoid leukosis. Nature 1981, 290, 475-480. [CrossRef]

124. Neel, B.G.; Hayward, W.S.; Robinson, H.L.; Fang, J.; Astrin, S.M. Avian leukosis virus-induced tumors have common proviral integration sites and synthesize discrete new RNAs: Oncogenesis by promoter insertion. Cell 1981, 23, 323-334. [CrossRef] 
125. Kalkat, M.; De Melo, J.; Hickman, K.A.; Lourenco, C.; Redel, C.; Resetca, D.; Tamachi, A.; Tu, W.B.; Penn, L.Z. MYC Deregulation in Primary Human Cancers. Genes 2017, 8, 151. [CrossRef]

126. Taub, R.; Kirsch, I.; Morton, C.; Lenoir, G.; Swan, D.; Tronick, S.; Aaronson, S.; Leder, P. Translocation of the c-myc gene into the immunoglobulin heavy chain locus in human Burkitt lymphoma and murine plasmacytoma cells. Proc. Natl. Acad. Sci. USA 1982, 79, 7837-7841. [CrossRef] [PubMed]

127. Dalla-Favera, R.; Bregni, M.; Erikson, J.; Patterson, D.; Gallo, R.C.; Croce, C.M. Human c-myc onc gene is located on the region of chromosome 8 that is translocated in Burkitt lymphoma cells. Proc. Natl. Acad. Sci. USA 1982, 79, 7824-7827. [CrossRef]

128. Schiavi, S.C.; Belasco, J.G.; Greenberg, M.E. Regulation of proto-oncogene mRNA stability. Biochim. Biophys. Acta 1992, 1114, 95-106. [CrossRef]

129. De Benedetti, A.; Graff, J.R. eIF-4E expression and its role in malignancies and metastases. Oncogene 2004, 23, 3189-3199. [CrossRef] [PubMed]

130. Ruggero, D.; Montanaro, L.; Ma, L.; Xu, W.; Londei, P.; Cordon-Cardo, C.; Pandolfi, P.P. The translation factor eIF-4E promotes tumor formation and cooperates with c-Myc in lymphomagenesis. Nat. Med. 2004, 10, 484-486. [CrossRef] [PubMed]

131. Gregory, M.A.; Hann, S.R. c-Myc proteolysis by the ubiquitin-proteasome pathway: Stabilization of c-Myc in Burkitt's lymphoma cells. Mol. Cell Biol. 2000, 20, 2423-2435. [CrossRef]

132. Herbst, A.; Salghetti, S.E.; Kim, S.Y.; Tansey, W.P. Multiple cell-type-specific elements regulate Myc protein stability. Oncogene 2004, 23, 3863-3871. [CrossRef]

133. Salghetti, S.E.; Kim, S.Y.; Tansey, W.P. Destruction of Myc by ubiquitin-mediated proteolysis: Cancer-associated and transforming mutations stabilize Myc. EMBO J. 1999, 18, 717-726. [CrossRef]

134. Kim, S.Y.; Herbst, A.; Tworkowski, K.A.; Salghetti, S.E.; Tansey, W.P. Skp2 regulates Myc protein stability and activity. Mol. Cell 2003, 11, 1177-1188. [CrossRef]

135. Welcker, M.; Orian, A.; Jin, J.; Grim, J.E.; Harper, J.W.; Eisenman, R.N.; Clurman, B.E. The Fbw7 tumor suppressor regulates glycogen synthase kinase 3 phosphorylation-dependent c-Myc protein degradation. Proc. Natl. Acad. Sci. USA 2004, 101, 9085-9090. [CrossRef] [PubMed]

136. Gabay, M.; Li, Y.; Felsher, D.W. MYC activation is a hallmark of cancer initiation and maintenance. Cold Spring Harb. Perspect. Med. 2014, 4. [CrossRef]

137. Feng, W.; Dean, D.C.; Hornicek, F.J.; Spentzos, D.; Hoffman, R.M.; Shi, H.; Duan, Z. Myc is a prognostic biomarker and potential therapeutic target in osteosarcoma. Ther. Adv. Med. Oncol. 2020, 12, 1758835920922055. [CrossRef] [PubMed]

138. Tapia, G.; Baptista, M.J.; Munoz-Marmol, A.M.; Gaafar, A.; Puente-Pomposo, M.; Garcia, O.; Marginet-Flinch, R.; Sanz, C.; Navarro, J.T.; Sancho, J.M.; et al. MYC protein expression is associated with poor prognosis in primary diffuse large B-cell lymphoma of the central nervous system. APMIS 2015, 123, 596-603. [CrossRef] [PubMed]

139. Tsiatis, A.C.; Herceg, M.E.; Keedy, V.L.; Halpern, J.L.; Holt, G.E.; Schwartz, H.S.; Cates, J.M. Prognostic significance of c-Myc expression in soft tissue leiomyosarcoma. Mod. Pathol. 2009, 22, 1432-1438. [CrossRef]

140. Soucek, L.; Evan, G.I. The ups and downs of Myc biology. Curr. Opin. Genet. Dev. 2010, 20, 91-95. [CrossRef] [PubMed]

141. Sansom, O.J.; Meniel, V.S.; Muncan, V.; Phesse, T.J.; Wilkins, J.A.; Reed, K.R.; Vass, J.K.; Athineos, D.; Clevers, H.; Clarke, A.R. Myc deletion rescues Apc deficiency in the small intestine. Nature 2007, 446, 676-679. [CrossRef] [PubMed]

142. Morton, J.P.; Sansom, O.J. MYC-y mice: From tumour initiation to therapeutic targeting of endogenous MYC. Mol. Oncol. 2013, 7, 248-258. [CrossRef]

143. Masso-Valles, D.; Soucek, L. Blocking Myc to Treat Cancer: Reflecting on Two Decades of Omomyc. Cells 2020, 9, 889. [CrossRef] [PubMed]

144. Eilers, M.; Picard, D.; Yamamoto, K.R.; Bishop, J.M. Chimaeras of myc oncoprotein and steroid receptors cause hormonedependent transformation of cells. Nature 1989, 340, 66-68. [CrossRef]

145. Karn, J.; Watson, J.V.; Lowe, A.D.; Green, S.M.; Vedeckis, W. Regulation of cell cycle duration by c-myc levels. Oncogene 1989, 4, $773-787$. [PubMed]

146. Mateyak, M.K.; Obaya, A.J.; Adachi, S.; Sedivy, J.M. Phenotypes of c-Myc-deficient rat fibroblasts isolated by targeted homologous recombination. Cell Growth Differ. 1997, 8, 1039-1048.

147. Grandori, C.; Eisenman, R.N. Myc target genes. Trends Biochem. Sci. 1997, 22, 177-181. [CrossRef]

148. Eisenman, R.N. Deconstructing myc. Genes Dev. 2001, 15, 2023-2030. [CrossRef] [PubMed]

149. Hartl, M. The Quest for Targets Executing MYC-Dependent Cell Transformation. Front. Oncol. 2016, 6, 132. [CrossRef]

150. Guo, J.; Li, T.; Schipper, J.; Nilson, K.A.; Fordjour, F.K.; Cooper, J.J.; Gordan, R.; Price, D.H. Sequence specificity incompletely defines the genome-wide occupancy of Myc. Genome Biol. 2014, 15, 482. [CrossRef]

151. Wyllie, A.H.; Rose, K.A.; Morris, R.G.; Steel, C.M.; Foster, E.; Spandidos, D.A. Rodent fibroblast tumours expressing human myc and ras genes: Growth, metastasis and endogenous oncogene expression. Br. J. Cancer 1987, 56, 251-259. [CrossRef] [PubMed]

152. Askew, D.S.; Ashmun, R.A.; Simmons, B.C.; Cleveland, J.L. Constitutive c-myc expression in an IL-3-dependent myeloid cell line suppresses cell cycle arrest and accelerates apoptosis. Oncogene 1991, 6, 1915-1922. [PubMed]

153. Evan, G.I.; Wyllie, A.H.; Gilbert, C.S.; Littlewood, T.D.; Land, H.; Brooks, M.; Waters, C.M.; Penn, L.Z.; Hancock, D.C. Induction of apoptosis in fibroblasts by c-myc protein. Cell 1992, 69, 119-128. [CrossRef]

154. Shi, Y.; Glynn, J.M.; Guilbert, L.J.; Cotter, T.G.; Bissonnette, R.P.; Green, D.R. Role for c-myc in activation-induced apoptotic cell death in T cell hybridomas. Science 1992, 257, 212-214. [CrossRef] [PubMed] 
155. Murphy, D.J.; Junttila, M.R.; Pouyet, L.; Karnezis, A.; Shchors, K.; Bui, D.A.; Brown-Swigart, L.; Johnson, L.; Evan, G.I. Distinct thresholds govern Myc's biological output in vivo. Cancer Cell 2008, 14, 447-457. [CrossRef]

156. Aubrey, B.J.; Kelly, G.L.; Janic, A.; Herold, M.J.; Strasser, A. How does p53 induce apoptosis and how does this relate to p53-mediated tumour suppression? Cell Death Differ. 2018, 25, 104-113. [CrossRef] [PubMed]

157. Shibue, T.; Takeda, K.; Oda, E.; Tanaka, H.; Murasawa, H.; Takaoka, A.; Morishita, Y.; Akira, S.; Taniguchi, T.; Tanaka, N. Integral role of Noxa in p53-mediated apoptotic response. Genes Dev. 2003, 17, 2233-2238. [CrossRef]

158. Villunger, A.; Michalak, E.M.; Coultas, L.; Mullauer, F.; Bock, G.; Ausserlechner, M.J.; Adams, J.M.; Strasser, A. p53- and drug-induced apoptotic responses mediated by BH3-only proteins puma and noxa. Science 2003, 302, 1036-1038. [CrossRef]

159. Jeffers, J.R.; Parganas, E.; Lee, Y.; Yang, C.; Wang, J.; Brennan, J.; MacLean, K.H.; Han, J.; Chittenden, T.; Ihle, J.N.; et al. Puma is an essential mediator of p53-dependent and -independent apoptotic pathways. Cancer Cell 2003, 4, 321-328. [CrossRef]

160. Naik, E.; Michalak, E.M.; Villunger, A.; Adams, J.M.; Strasser, A. Ultraviolet radiation triggers apoptosis of fibroblasts and skin keratinocytes mainly via the BH3-only protein Noxa. J. Cell Biol. 2007, 176, 415-424. [CrossRef]

161. Michalak, E.M.; Villunger, A.; Adams, J.M.; Strasser, A. In several cell types tumour suppressor p53 induces apoptosis largely via Puma but Noxa can contribute. Cell Death Differ 2008, 15, 1019-1029. [CrossRef]

162. Happo, L.; Cragg, M.S.; Phipson, B.; Haga, J.M.; Jansen, E.S.; Herold, M.J.; Dewson, G.; Michalak, E.M.; Vandenberg, C.J.; Smyth, G.K.; et al. Maximal killing of lymphoma cells by DNA damage-inducing therapy requires not only the p53 targets Puma and Noxa, but also Bim. Blood 2010, 116, 5256-5267. [CrossRef]

163. Valente, L.J.; Aubrey, B.J.; Herold, M.J.; Kelly, G.L.; Happo, L.; Scott, C.L.; Newbold, A.; Johnstone, R.W.; Huang, D.C.; Vassilev, L.T.; et al. Therapeutic Response to Non-genotoxic Activation of p53 by Nutlin3a Is Driven by PUMA-Mediated Apoptosis in Lymphoma Cells. Cell Rep. 2016, 14, 1858-1866. [CrossRef] [PubMed]

164. Li, M.; He, Y.; Dubois, W.; Wu, X.; Shi, J.; Huang, J. Distinct regulatory mechanisms and functions for p53-activated and p53-repressed DNA damage response genes in embryonic stem cells. Mol. Cell 2012, 46, 30-42. [CrossRef] [PubMed]

165. Kenzelmann Broz, D.; Spano Mello, S.; Bieging, K.T.; Jiang, D.; Dusek, R.L.; Brady, C.A.; Sidow, A.; Attardi, L.D. Global genomic profiling reveals an extensive p53-regulated autophagy program contributing to key p53 responses. Genes Dev. 2013, 27, $1016-1031$. [CrossRef]

166. Tonelli, C.; Morelli, M.J.; Bianchi, S.; Rotta, L.; Capra, T.; Sabo, A.; Campaner, S.; Amati, B. Genome-wide analysis of p53 transcriptional programs in B cells upon exposure to genotoxic stress in vivo. Oncotarget 2015, 6, 24611-24626. [CrossRef]

167. Selvakumaran, M.; Lin, H.K.; Miyashita, T.; Wang, H.G.; Krajewski, S.; Reed, J.C.; Hoffman, B.; Liebermann, D. Immediate early up-regulation of bax expression by p53 but not TGF beta 1: A paradigm for distinct apoptotic pathways. Oncogene 1994, 9, 1791-1798 [PubMed]

168. Thornborrow, E.C.; Patel, S.; Mastropietro, A.E.; Schwartzfarb, E.M.; Manfredi, J.J. A conserved intronic response element mediates direct p53-dependent transcriptional activation of both the human and murine bax genes. Oncogene 2002, 21, 990-999. [CrossRef] [PubMed]

169. Robles, A.I.; Bemmels, N.A.; Foraker, A.B.; Harris, C.C. APAF-1 is a transcriptional target of p53 in DNA damage-induced apoptosis. Cancer Res. 2001, 61, 6660-6664.

170. Barak, Y.; Juven, T.; Haffner, R.; Oren, M. mdm2 expression is induced by wild type p53 activity. EMBO J. 1993, 12, 461-468. [CrossRef]

171. Wu, X.; Bayle, J.H.; Olson, D.; Levine, A.J. The p53-mdm-2 autoregulatory feedback loop. Genes Dev. 1993, 7, 1126-1132. [CrossRef] [PubMed]

172. Haupt, Y.; Maya, R.; Kazaz, A.; Oren, M. Mdm2 promotes the rapid degradation of p53. Nature 1997, 387, 296-299. [CrossRef]

173. Honda, R.; Tanaka, H.; Yasuda, H. Oncoprotein MDM2 is a ubiquitin ligase E3 for tumor suppressor p53. FEBS Lett. 1997, 420, 25-27. [CrossRef]

174. Kubbutat, M.H.; Jones, S.N.; Vousden, K.H. Regulation of p53 stability by Mdm2. Nature 1997, 387, 299-303. [CrossRef]

175. Kamijo, T.; Weber, J.D.; Zambetti, G.; Zindy, F.; Roussel, M.F.; Sherr, C.J. Functional and physical interactions of the ARF tumor suppressor with p53 and Mdm2. Proc. Natl. Acad. Sci. USA 1998, 95, 8292-8297. [CrossRef] [PubMed]

176. Pomerantz, J.; Schreiber-Agus, N.; Liegeois, N.J.; Silverman, A.; Alland, L.; Chin, L.; Potes, J.; Chen, K.; Orlow, I.; Lee, H.W.; et al. The Ink4a tumor suppressor gene product, p19Arf, interacts with MDM2 and neutralizes MDM2's inhibition of p53. Cell 1998, 92, 713-723. [CrossRef]

177. Stott, F.J.; Bates, S.; James, M.C.; McConnell, B.B.; Starborg, M.; Brookes, S.; Palmero, I.; Ryan, K.; Hara, E.; Vousden, K.H.; et al The alternative product from the human CDKN2A locus, p14(ARF), participates in a regulatory feedback loop with p53 and MDM2. EMBO J. 1998, 17, 5001-5014. [CrossRef]

178. Zhang, Y.; Xiong, Y.; Yarbrough, W.G. ARF promotes MDM2 degradation and stabilizes p53: ARF-INK4a locus deletion impairs both the $\mathrm{Rb}$ and 553 tumor suppression pathways. Cell 1998, 92, 725-734. [CrossRef]

179. Roth, J.; Dobbelstein, M.; Freedman, D.A.; Shenk, T.; Levine, A.J. Nucleo-cytoplasmic shuttling of the hdm2 oncoprotein regulates the levels of the p53 protein via a pathway used by the human immunodeficiency virus rev protein. EMBO J. 1998, 17, 554-564. [CrossRef]

180. Sherr, C.J. Tumor surveillance via the ARF-p53 pathway. Genes Dev. 1998, 12, 2984-2991. [CrossRef]

181. Zindy, F.; Eischen, C.M.; Randle, D.H.; Kamijo, T.; Cleveland, J.L.; Sherr, C.J.; Roussel, M.F. Myc signaling via the ARF tumor suppressor regulates p53-dependent apoptosis and immortalization. Genes Dev. 1998, 12, 2424-2433. [CrossRef] 
182. Eischen, C.M.; Weber, J.D.; Roussel, M.F.; Sherr, C.J.; Cleveland, J.L. Disruption of the ARF-Mdm2-p53 tumor suppressor pathway in Myc-induced lymphomagenesis. Genes Dev. 1999, 13, 2658-2669. [CrossRef] [PubMed]

183. Jacobsen, K.A.; Prasad, V.S.; Sidman, C.L.; Osmond, D.G. Apoptosis and macrophage-mediated deletion of precursor B cells in the bone marrow of E mu-myc transgenic mice. Blood 1994, 84, 2784-2794. [CrossRef] [PubMed]

184. Schmitt, C.A.; McCurrach, M.E.; De Stanchina, E.; Wallace-Brodeur, R.R.; Lowe, S.W. INK4a/ARF mutations accelerate lymphomagenesis and promote chemoresistance by disabling p53. Genes Dev. 1999, 13, 2670-2677. [CrossRef]

185. Hsu, B.; Marin, M.C.; El-Naggar, A.K.; Stephens, L.C.; Brisbay, S.; McDonnell, T.J. Evidence that c-myc mediated apoptosis does not require wild-type p53 during lymphomagenesis. Oncogene 1995, 11, 175-179. [PubMed]

186. Hemann, M.T.; Bric, A.; Teruya-Feldstein, J.; Herbst, A.; Nilsson, J.A.; Cordon-Cardo, C.; Cleveland, J.L.; Tansey, W.P.; Lowe, S.W. Evasion of the p53 tumour surveillance network by tumour-derived MYC mutants. Nature 2005, 436, 807-811. [CrossRef]

187. Muthalagu, N.; Junttila, M.R.; Wiese, K.E.; Wolf, E.; Morton, J.; Bauer, B.; Evan, G.I.; Eilers, M.; Murphy, D.J. BIM is the primary mediator of MYC-induced apoptosis in multiple solid tissues. Cell Rep. 2014, 8, 1347-1353. [CrossRef] [PubMed]

188. Chang, D.W.; Claassen, G.F.; Hann, S.R.; Cole, M.D. The c-Myc transactivation domain is a direct modulator of apoptotic versus proliferative signals. Mol. Cell Biol. 2000, 20, 4309-4319. [CrossRef]

189. Mitchell, K.O.; Ricci, M.S.; Miyashita, T.; Dicker, D.T.; Jin, Z.; Reed, J.C.; El-Deiry, W.S. Bax is a transcriptional target and mediator of c-myc-induced apoptosis. Cancer Res. 2000, 60, 6318-6325.

190. Eischen, C.M.; Packham, G.; Nip, J.; Fee, B.E.; Hiebert, S.W.; Zambetti, G.P.; Cleveland, J.L. Bcl-2 is an apoptotic target suppressed by both c-Myc and E2F-1. Oncogene 2001, 20, 6983-6993. [CrossRef]

191. Maclean, K.H.; Keller, U.B.; Rodriguez-Galindo, C.; Nilsson, J.A.; Cleveland, J.L. c-Myc augments gamma irradiation-induced apoptosis by suppressing Bcl-XL. Mol. Cell Biol. 2003, 23, 7256-7270. [CrossRef] [PubMed]

192. Neiman, P.E.; Thomas, S.J.; Loring, G. Induction of apoptosis during normal and neoplastic B-cell development in the bursa of Fabricius. Proc. Natl. Acad. Sci. USA 1991, 88, 5857-5861. [CrossRef] [PubMed]

193. McDonnell, T.J.; Deane, N.; Platt, F.M.; Nunez, G.; Jaeger, U.; McKearn, J.P.; Korsmeyer, S.J. bcl-2-immunoglobulin transgenic mice demonstrate extended B cell survival and follicular lymphoproliferation. Cell 1989, 57, 79-88. [CrossRef]

194. McDonnell, T.J.; Nunez, G.; Platt, F.M.; Hockenberry, D.; London, L.; McKearn, J.P.; Korsmeyer, S.J. Deregulated Bcl-2 immunoglobulin transgene expands a resting but responsive immunoglobulin $\mathrm{M}$ and D-expressing B-cell population. Mol. Cell Biol. 1990, 10, 1901-1907. [CrossRef] [PubMed]

195. Strasser, A.; Whittingham, S.; Vaux, D.L.; Bath, M.L.; Adams, J.M.; Cory, S.; Harris, A.W. Enforced BCL2 expression in B-lymphoid cells prolongs antibody responses and elicits autoimmune disease. Proc. Natl. Acad. Sci. USA 1991, 88, 8661-8665. [CrossRef]

196. Nunez, G.; Seto, M.; Seremetis, S.; Ferrero, D.; Grignani, F.; Korsmeyer, S.J.; Dalla-Favera, R. Growth- and tumor-promoting effects of deregulated BCL2 in human B-lymphoblastoid cells. Proc. Natl. Acad. Sci. USA 1989, 86, 4589-4593. [CrossRef] [PubMed]

197. Limpens, J.; Stad, R.; Vos, C.; De Vlaam, C.; De Jong, D.; Van Ommen, G.J.; Schuuring, E.; Kluin, P.M. Lymphoma-associated translocation $\mathrm{t}(14 ; 18)$ in blood B cells of normal individuals. Blood 1995, 85, 2528-2536. [CrossRef] [PubMed]

198. Knezevich, S.; Ludkovski, O.; Salski, C.; Lestou, V.; Chhanabhai, M.; Lam, W.; Klasa, R.; Connors, J.M.; Dyer, M.J.; Gascoyne, R.D.; et al. Concurrent translocation of BCL2 and MYC with a single immunoglobulin locus in high-grade B-cell lymphomas. Leukemia 2005, 19, 659-663. [CrossRef] [PubMed]

199. Mukhopadhyay, S.; Readling, J.; Cotter, P.D.; Shrimpton, A.E.; Sidhu, J.S. Transformation of follicular lymphoma to Burkitt-like lymphoma within a single lymph node. Hum. Pathol. 2005, 36, 571-575. [CrossRef]

200. Arcinas, M.; Heckman, C.A.; Mehew, J.W.; Boxer, L.M. Molecular mechanisms of transcriptional control of bcl-2 and c-myc in follicular and transformed lymphoma. Cancer Res. 2001, 61, 5202-5206.

201. Dyer, M.J.; Lillington, D.M.; Bastard, C.; Tilly, H.; Lens, D.; Heward, J.M.; Stranks, G.; Morilla, R.; Monrad, S.; Guglielmi, P.; et al. Concurrent activation of MYC and BCL2 in B cell non-Hodgkin lymphoma cell lines by translocation of both oncogenes to the same immunoglobulin heavy chain locus. Leukemia 1996, 10, 1198-1208. [PubMed]

202. Martin-Subero, J.I.; Odero, M.D.; Hernandez, R.; Cigudosa, J.C.; Agirre, X.; Saez, B.; Sanz-Garcia, E.; Ardanaz, M.T.; Novo, F.J.; Gascoyne, R.D.; et al. Amplification of IGH/MYC fusion in clinically aggressive IGH/BCL2-positive germinal center B-cell lymphomas. Genes Chromosomes Cancer 2005, 43, 414-423. [CrossRef] [PubMed]

203. Berger, R.; Flexor, M.; Le Coniat, M.; Larsen, C.J. Presence of three recurrent chromosomal reaarrangements, $t(2 ; 3)(\mathrm{p} 12 ; \mathrm{q} 37)$, $\operatorname{del}(8)(q 24)$, and $t(14 ; 18)$, in an acute lymphoblastic leukemia. Cancer Genet. Cytogenet. 1996, 86, 76-79. [CrossRef]

204. Pegoraro, L.; Palumbo, A.; Erikson, J.; Falda, M.; Giovanazzo, B.; Emanuel, B.S.; Rovera, G.; Nowell, P.C.; Croce, C.M. A 14;18 and an 8;14 chromosome translocation in a cell line derived from an acute B-cell leukemia. Proc. Natl. Acad. Sci. USA 1984, 81, 7166-7170. [CrossRef] [PubMed]

205. Tsujimoto, Y. Stress-resistance conferred by high level of bcl-2 alpha protein in human B lymphoblastoid cell. Oncogene 1989, 4, 1331-1336.

206. McDonnell, T.J.; Korsmeyer, S.J. Progression from lymphoid hyperplasia to high-grade malignant lymphoma in mice transgenic for the $\mathrm{t}(14 ; 18)$. Nature 1991, 349, 254-256. [CrossRef]

207. Strasser, A.; Harris, A.W.; Cory, S. E mu-bcl-2 transgene facilitates spontaneous transformation of early pre-B and immunoglobulinsecreting cells but not T cells. Oncogene 1993, 8, 1-9.

208. Letai, A.; Sorcinelli, M.D.; Beard, C.; Korsmeyer, S.J. Antiapoptotic BCL-2 is required for maintenance of a model leukemia. Cancer Cell 2004, 6, 241-249. [CrossRef] 
209. Bissonnette, R.P.; Echeverri, F.; Mahboubi, A.; Green, D.R. Apoptotic cell death induced by c-myc is inhibited by bcl-2. Nature 1992, 359, 552-554. [CrossRef]

210. Fanidi, A.; Harrington, E.A.; Evan, G.I. Cooperative interaction between c-myc and bcl-2 proto-oncogenes. Nature 1992, 359, 554-556. [CrossRef]

211. Wagner, A.J.; Small, M.B.; Hay, N. Myc-mediated apoptosis is blocked by ectopic expression of Bcl-2. Mol. Cell Biol. 1993, 13, 2432-2440. [CrossRef] [PubMed]

212. Brunelle, J.K.; Ryan, J.; Yecies, D.; Opferman, J.T.; Letai, A. MCL-1-dependent leukemia cells are more sensitive to chemotherapy than BCL-2-dependent counterparts. J. Cell Biol. 2009, 187, 429-442. [CrossRef]

213. Campbell, K.J.; Bath, M.L.; Turner, M.L.; Vandenberg, C.J.; Bouillet, P.; Metcalf, D.; Scott, C.L.; Cory, S. Elevated Mcl-1 perturbs lymphopoiesis, promotes transformation of hematopoietic stem/progenitor cells, and enhances drug resistance. Blood 2010, 116, 3197-3207. [CrossRef] [PubMed]

214. Cheung, W.C.; Kim, J.S.; Linden, M.; Peng, L.; Van Ness, B.; Polakiewicz, R.D.; Janz, S. Novel targeted deregulation of c-Myc cooperates with Bcl-X(L) to cause plasma cell neoplasms in mice. J. Clin. Investig. 2004, 113, 1763-1773. [CrossRef] [PubMed]

215. Linden, M.; Kirchhof, N.; Carlson, C.; Van Ness, B. Targeted overexpression of Bcl-XL in B-lymphoid cells results in lymphoproliferative disease and plasma cell malignancies. Blood 2004, 103, 2779-2786. [CrossRef]

216. Swanson, P.J.; Kuslak, S.L.; Fang, W.; Tze, L.; Gaffney, P.; Selby, S.; Hippen, K.L.; Nunez, G.; Sidman, C.L.; Behrens, T.W. Fatal acute lymphoblastic leukemia in mice transgenic for B cell-restricted bcl-xL and c-myc. J. Immunol. 2004, 172, 6684-6691. [CrossRef]

217. Kelly, P.N.; Puthalakath, H.; Adams, J.M.; Strasser, A. Endogenous bcl-2 is not required for the development of Emu-myc-induced B-cell lymphoma. Blood 2007, 109, 4907-4913. [CrossRef] [PubMed]

218. Kelly, P.N.; Grabow, S.; Delbridge, A.R.; Strasser, A.; Adams, J.M. Endogenous Bcl-xL is essential for Myc-driven lymphomagenesis in mice. Blood 2011, 118, 6380-6386. [CrossRef] [PubMed]

219. Kelly, G.L.; Grabow, S.; Glaser, S.P.; Fitzsimmons, L.; Aubrey, B.J.; Okamoto, T.; Valente, L.J.; Robati, M.; Tai, L.; Fairlie, W.D.; et al. Targeting of MCL-1 kills MYC-driven mouse and human lymphomas even when they bear mutations in p53. Genes Dev. 2014, 28, 58-70. [CrossRef] [PubMed]

220. Eischen, C.M.; Roussel, M.F.; Korsmeyer, S.J.; Cleveland, J.L. Bax loss impairs Myc-induced apoptosis and circumvents the selection of p53 mutations during Myc-mediated lymphomagenesis. Mol. Cell Biol. 2001, 21, 7653-7662. [CrossRef] [PubMed]

221. Herbst, R.S.; Frankel, S.R. Oblimersen sodium (Genasense bcl-2 antisense oligonucleotide): A rational therapeutic to enhance apoptosis in therapy of lung cancer. Clin. Cancer Res. 2004, 10, 4245s-4248s. [CrossRef] [PubMed]

222. Tolcher, A.W.; Chi, K.; Kuhn, J.; Gleave, M.; Patnaik, A.; Takimoto, C.; Schwartz, G.; Thompson, I.; Berg, K.; D’Aloisio, S.; et al. A phase II, pharmacokinetic, and biological correlative study of oblimersen sodium and docetaxel in patients with hormone-refractory prostate cancer. Clin. Cancer Res. 2005, 11, 3854-3861. [CrossRef]

223. Muchmore, S.W.; Sattler, M.; Liang, H.; Meadows, R.P.; Harlan, J.E.; Yoon, H.S.; Nettesheim, D.; Chang, B.S.; Thompson, C.B.; Wong, S.L.; et al. X-ray and NMR structure of human Bcl-xL, an inhibitor of programmed cell death. Nature 1996, 381, 335-341. [CrossRef]

224. Sattler, M.; Liang, H.; Nettesheim, D.; Meadows, R.P.; Harlan, J.E.; Eberstadt, M.; Yoon, H.S.; Shuker, S.B.; Chang, B.S.; Minn, A.J.; et al. Structure of Bcl-xL-Bak peptide complex: Recognition between regulators of apoptosis. Science 1997, 275, 983-986. [CrossRef] [PubMed]

225. Czabotar, P.E.; Lee, E.F.; Van Delft, M.F.; Day, C.L.; Smith, B.J.; Huang, D.C.; Fairlie, W.D.; Hinds, M.G.; Colman, P.M. Structural insights into the degradation of Mcl-1 induced by BH3 domains. Proc. Natl. Acad. Sci. USA 2007, 104, 6217-6222. [CrossRef]

226. Day, C.L.; Smits, C.; Fan, F.C.; Lee, E.F.; Fairlie, W.D.; Hinds, M.G. Structure of the BH3 domains from the p53-inducible BH3-only proteins Noxa and Puma in complex with Mcl-1. J. Mol. Biol. 2008, 380, 958-971. [CrossRef]

227. Lee, E.F.; Sadowsky, J.D.; Smith, B.J.; Czabotar, P.E.; Peterson-Kaufman, K.J.; Colman, P.M.; Gellman, S.H.; Fairlie, W.D. Highresolution structural characterization of a helical alpha/beta-peptide foldamer bound to the anti-apoptotic protein Bcl-xL. Angew. Chem. Int. Ed. Engl. 2009, 48, 4318-4322. [CrossRef]

228. Petros, A.M.; Olejniczak, E.T.; Fesik, S.W. Structural biology of the Bcl-2 family of proteins. Biochim. Biophys. Acta 2004, 1644, 83-94. [CrossRef]

229. Smits, C.; Czabotar, P.E.; Hinds, M.G.; Day, C.L. Structural plasticity underpins promiscuous binding of the prosurvival protein A1. Structure 2008, 16, 818-829. [CrossRef] [PubMed]

230. Oltersdorf, T.; Elmore, S.W.; Shoemaker, A.R.; Armstrong, R.C.; Augeri, D.J.; Belli, B.A.; Bruncko, M.; Deckwerth, T.L.; Dinges, J.; Hajduk, P.J.; et al. An inhibitor of Bcl-2 family proteins induces regression of solid tumours. Nature 2005, 435, 677-681. [CrossRef]

231. Van Delft, M.F.; Wei, A.H.; Mason, K.D.; Vandenberg, C.J.; Chen, L.; Czabotar, P.E.; Willis, S.N.; Scott, C.L.; Day, C.L.; Cory, S.; et al. The BH3 mimetic ABT-737 targets selective Bcl-2 proteins and efficiently induces apoptosis via Bak/Bax if Mcl-1 is neutralized. Cancer Cell 2006, 10, 389-399. [CrossRef] [PubMed]

232. Shoemaker, A.R.; Mitten, M.J.; Adickes, J.; Ackler, S.; Refici, M.; Ferguson, D.; Oleksijew, A.; O'Connor, J.M.; Wang, B.; Frost, D.J.; et al. Activity of the Bcl-2 family inhibitor ABT-263 in a panel of small cell lung cancer xenograft models. Clin. Cancer Res. 2008, 14, 3268-3277. [CrossRef]

233. Tse, C.; Shoemaker, A.R.; Adickes, J.; Anderson, M.G.; Chen, J.; Jin, S.; Johnson, E.F.; Marsh, K.C.; Mitten, M.J.; Nimmer, P.; et al. ABT-263: A potent and orally bioavailable Bcl-2 family inhibitor. Cancer Res. 2008, 68, 3421-3428. [CrossRef] 
234. Rudin, C.M.; Hann, C.L.; Garon, E.B.; Ribeiro de Oliveira, M.; Bonomi, P.D.; Camidge, D.R.; Chu, Q.; Giaccone, G.; Khaira, D.; Ramalingam, S.S.; et al. Phase II study of single-agent navitoclax (ABT-263) and biomarker correlates in patients with relapsed small cell lung cancer. Clin. Cancer Res. 2012, 18, 3163-3169. [CrossRef] [PubMed]

235. Gandhi, L.; Camidge, D.R.; Ribeiro de Oliveira, M.; Bonomi, P.; Gandara, D.; Khaira, D.; Hann, C.L.; McKeegan, E.M.; Litvinovich, E.; Hemken, P.M.; et al. Phase I study of Navitoclax (ABT-263), a novel Bcl-2 family inhibitor, in patients with small-cell lung cancer and other solid tumors. J. Clin. Oncol. 2011, 29, 909-916. [CrossRef]

236. Mason, K.D.; Carpinelli, M.R.; Fletcher, J.I.; Collinge, J.E.; Hilton, A.A.; Ellis, S.; Kelly, P.N.; Ekert, P.G.; Metcalf, D.; Roberts, A.W.; et al. Programmed anuclear cell death delimits platelet life span. Cell 2007, 128, 1173-1186. [CrossRef] [PubMed]

237. Souers, A.J.; Leverson, J.D.; Boghaert, E.R.; Ackler, S.L.; Catron, N.D.; Chen, J.; Dayton, B.D.; Ding, H.; Enschede, S.H.; Fairbrother, W.J.; et al. ABT-199, a potent and selective BCL-2 inhibitor, achieves antitumor activity while sparing platelets. Nat. Med. 2013, 19, 202-208. [CrossRef]

238. Seymour, J.F.; Ma, S.; Brander, D.M.; Choi, M.Y.; Barrientos, J.; Davids, M.S.; Anderson, M.A.; Beaven, A.W.; Rosen, S.T.; Tam, C.S.; et al. Venetoclax plus rituximab in relapsed or refractory chronic lymphocytic leukaemia: A phase 1b study. Lancet Oncol. 2017, 18, 230-240. [CrossRef]

239. Pollyea, D.A.; Pratz, K.; Letai, A.; Jonas, B.A.; Wei, A.H.; Pullarkat, V.; Konopleva, M.; Thirman, M.J.; Arellano, M.; Becker, P.S.; et al. Venetoclax with azacitidine or decitabine in patients with newly diagnosed acute myeloid leukemia: Long term follow-up from a phase $1 \mathrm{~b}$ study. Am. J. Hematol. 2020. [CrossRef]

240. DiNardo, C.D.; Jonas, B.A.; Pullarkat, V.; Thirman, M.J.; Garcia, J.S.; Wei, A.H.; Konopleva, M.; Dohner, H.; Letai, A.; Fenaux, P.; et al. Azacitidine and Venetoclax in Previously Untreated Acute Myeloid Leukemia. N. Engl. J. Med. 2020, 383, 617-629. [CrossRef]

241. Balachander, S.B.; Criscione, S.W.; Byth, K.F.; Cidado, J.; Adam, A.; Lewis, P.; Macintyre, T.; Wen, S.; Lawson, D.; Burke, K.; et al. AZD4320, A Dual Inhibitor of Bcl-2 and Bcl-xL, Induces Tumor Regression in Hematologic Cancer Models without Dose-limiting Thrombocytopenia. Clin. Cancer Res. 2020. [CrossRef]

242. Patterson, C.M.; Balachander, S.B.; Grant, I.; Pop-Damkov, P.; Kelly, B.; McCoull, W.; Parker, J.; Giannis, M.; Hill, K.J.; Gibbons, F.D.; et al. Design and optimisation of dendrimer-conjugated Bcl-2/xL inhibitor, AZD0466, with improved therapeutic index for cancer therapy. Commun. Biol. 2021, 4, 112. [CrossRef]

243. Kotschy, A.; Szlavik, Z.; Murray, J.; Davidson, J.; Maragno, A.L.; Le Toumelin-Braizat, G.; Chanrion, M.; Kelly, G.L.; Gong, J.N.; Moujalled, D.M.; et al. The MCL1 inhibitor S63845 is tolerable and effective in diverse cancer models. Nature 2016, 538, 477-482. [CrossRef]

244. Tron, A.E.; Belmonte, M.A.; Adam, A.; Aquila, B.M.; Boise, L.H.; Chiarparin, E.; Cidado, J.; Embrey, K.J.; Gangl, E.; Gibbons, F.D.; et al. Discovery of Mcl-1-specific inhibitor AZD5991 and preclinical activity in multiple myeloma and acute myeloid leukemia. Nat. Commun. 2018, 9, 5341. [CrossRef]

245. Caenepeel, S.; Brown, S.P.; Belmontes, B.; Moody, G.; Keegan, K.S.; Chui, D.; Whittington, D.A.; Huang, X.; Poppe, L.; Cheng, A.C.; et al. AMG 176, a Selective MCL1 Inhibitor, Is Effective in Hematologic Cancer Models Alone and in Combination with Established Therapies. Cancer Discov. 2018, 8, 1582-1597. [CrossRef] [PubMed]

246. Lessene, G.; Czabotar, P.E.; Sleebs, B.E.; Zobel, K.; Lowes, K.N.; Adams, J.M.; Baell, J.B.; Colman, P.M.; Deshayes, K.; Fairbrother, W.J.; et al. Structure-guided design of a selective BCL-X(L) inhibitor. Nat. Chem. Biol. 2013, 9, 390-397. [CrossRef] [PubMed]

247. Leverson, J.D.; Phillips, D.C.; Mitten, M.J.; Boghaert, E.R.; Diaz, D.; Tahir, S.K.; Belmont, L.D.; Nimmer, P.; Xiao, Y.; Ma, X.M.; et al. Exploiting selective BCL-2 family inhibitors to dissect cell survival dependencies and define improved strategies for cancer therapy. Sci. Transl. Med. 2015, 7, 279ra240. [CrossRef] [PubMed]

248. Soderquist, R.S.; Crawford, L.; Liu, E.; Lu, M.; Agarwal, A.; Anderson, G.R.; Lin, K.H.; Winter, P.S.; Cakir, M.; Wood, K.C. Systematic mapping of BCL-2 gene dependencies in cancer reveals molecular determinants of BH3 mimetic sensitivity. Nat. Commun. 2018, 9, 3513. [CrossRef]

249. Arulananda, S.; O’Brien, M.; Evangelista, M.; Harris, T.J.; Steinohrt, N.S.; Jenkins, L.J.; Walkiewicz, M.; O'Donoghue, R.; Poh, A.R.; Thapa, B.; et al. BCL-XL is an actionable target for treatment of malignant pleural mesothelioma. Cell Death Discov. 2020, 6, 114. [CrossRef]

250. Weeden, C.E.; Ah-Cann, C.; Holik, A.Z.; Pasquet, J.; Garnier, J.M.; Merino, D.; Lessene, G.; Asselin-Labat, M.L. Dual inhibition of BCL-XL and MCL-1 is required to induce tumour regression in lung squamous cell carcinomas sensitive to FGFR inhibition. Oncogene 2018. [CrossRef] [PubMed]

251. Mukherjee, N.; Skees, J.; Todd, K.J.; West, D.A.; Lambert, K.A.; Robinson, W.A.; Amato, C.M.; Couts, K.L.; Van Gulick, R.; MacBeth, M.; et al. MCL1 inhibitors S63845/MIK665 plus Navitoclax synergistically kill difficult-to-treat melanoma cells. Cell Death Dis. 2020, 11, 443. [CrossRef] [PubMed]

252. Mukherjee, N.; Amato, C.M.; Skees, J.; Todd, K.J.; Lambert, K.A.; Robinson, W.A.; Van Gulick, R.; Weight, R.M.; Dart, C.R.; Tobin, R.P.; et al. Simultaneously Inhibiting BCL2 and MCL1 Is a Therapeutic Option for Patients with Advanced Melanoma. Cancers 2020, 12, 2182. [CrossRef]

253. Nangia, V.; Siddiqui, F.M.; Caenepeel, S.; Timonina, D.; Bilton, S.J.; Phan, N.; Gomez-Caraballo, M.; Archibald, H.L.; Li, C.; Fraser, C.; et al. Exploiting MCL1 Dependency with Combination MEK + MCL1 Inhibitors Leads to Induction of Apoptosis and Tumor Regression in KRAS-Mutant Non-Small Cell Lung Cancer. Cancer Discov. 2018, 8, 1598-1613. [CrossRef] 
254. Duffy, M.J.; Crown, J. Drugging "undruggable" genes for cancer treatment: Are we making progress? Int. J. Cancer 2021, 148 , 8-17. [CrossRef]

255. Berg, T.; Cohen, S.B.; Desharnais, J.; Sonderegger, C.; Maslyar, D.J.; Goldberg, J.; Boger, D.L.; Vogt, P.K. Small-molecule antagonists of Myc/Max dimerization inhibit Myc-induced transformation of chicken embryo fibroblasts. Proc. Natl. Acad. Sci. USA 2002, 99, 3830-3835. [CrossRef]

256. Wang, H.; Hammoudeh, D.I.; Follis, A.V.; Reese, B.E.; Lazo, J.S.; Metallo, S.J.; Prochownik, E.V. Improved low molecular weight Myc-Max inhibitors. Mol. Cancer Ther. 2007, 6, 2399-2408. [CrossRef]

257. Xu, Y.; Shi, J.; Yamamoto, N.; Moss, J.A.; Vogt, P.K.; Janda, K.D. A credit-card library approach for disrupting protein-protein interactions. Bioorg. Med. Chem. 2006, 14, 2660-2673. [CrossRef]

258. Yin, X.; Giap, C.; Lazo, J.S.; Prochownik, E.V. Low molecular weight inhibitors of Myc-Max interaction and function. Oncogene 2003, 22, 6151-6159. [CrossRef] [PubMed]

259. Soucek, L.; Jucker, R.; Panacchia, L.; Ricordy, R.; Tato, F.; Nasi, S. Omomyc, a potential Myc dominant negative, enhances Myc-induced apoptosis. Cancer Res. 2002, 62, 3507-3510. [PubMed]

260. Soucek, L.; Helmer-Citterich, M.; Sacco, A.; Jucker, R.; Cesareni, G.; Nasi, S. Design and properties of a Myc derivative that efficiently homodimerizes. Oncogene 1998, 17, 2463-2472. [CrossRef]

261. Savino, M.; Annibali, D.; Carucci, N.; Favuzzi, E.; Cole, M.D.; Evan, G.I.; Soucek, L.; Nasi, S. The action mechanism of the Myc inhibitor termed Omomyc may give clues on how to target Myc for cancer therapy. PLoS ONE 2011, 6, e22284. [CrossRef] [PubMed]

262. Demma, M.J.; Mapelli, C.; Sun, A.; Bodea, S.; Ruprecht, B.; Javaid, S.; Wiswell, D.; Muise, E.; Chen, S.; Zelina, J.; et al. Omomyc Reveals New Mechanisms To Inhibit the MYC Oncogene. Mol. Cell Biol. 2019, 39. [CrossRef] [PubMed]

263. Jung, L.A.; Gebhardt, A.; Koelmel, W.; Ade, C.P.; Walz, S.; Kuper, J.; Von Eyss, B.; Letschert, S.; Redel, C.; D’Artista, L.; et al. OmoMYC blunts promoter invasion by oncogenic MYC to inhibit gene expression characteristic of MYC-dependent tumors. Oncogene 2017, 36, 1911-1924. [CrossRef] [PubMed]

264. Annibali, D.; Whitfield, J.R.; Favuzzi, E.; Jauset, T.; Serrano, E.; Cuartas, I.; Redondo-Campos, S.; Folch, G.; Gonzalez-Junca, A.; Sodir, N.M.; et al. Myc inhibition is effective against glioma and reveals a role for Myc in proficient mitosis. Nat. Commun. 2014, 5, 4632. [CrossRef]

265. Sodir, N.M.; Kortlever, R.M.; Barthet, V.J.A.; Campos, T.; Pellegrinet, L.; Kupczak, S.; Anastasiou, P.; Swigart, L.B.; Soucek, L.; Arends, M.J.; et al. MYC Instructs and Maintains Pancreatic Adenocarcinoma Phenotype. Cancer Discov. 2020, 10, 588-607. [CrossRef] [PubMed]

266. Soucek, L.; Whitfield, J.R.; Sodir, N.M.; Masso-Valles, D.; Serrano, E.; Karnezis, A.N.; Swigart, L.B.; Evan, G.I. Inhibition of Myc family proteins eradicates KRas-driven lung cancer in mice. Genes Dev. 2013, 27, 504-513. [CrossRef]

267. Soucek, L.; Whitfield, J.; Martins, C.P.; Finch, A.J.; Murphy, D.J.; Sodir, N.M.; Karnezis, A.N.; Swigart, L.B.; Nasi, S.; Evan, G.I. Modelling Myc inhibition as a cancer therapy. Nature 2008, 455, 679-683. [CrossRef]

268. Beaulieu, M.E.; Jauset, T.; Masso-Valles, D.; Martinez-Martin, S.; Rahl, P.; Maltais, L.; Zacarias-Fluck, M.F.; Casacuberta-Serra, S.; Serrano Del Pozo, E.; Fiore, C.; et al. Intrinsic cell-penetrating activity propels Omomyc from proof of concept to viable anti-MYC therapy. Sci. Transl. Med. 2019, 11. [CrossRef] [PubMed]

269. Webb, M.S.; Tortora, N.; Cremese, M.; Kozlowska, H.; Blaquiere, M.; Devine, D.V.; Kornbrust, D.J. Toxicity and toxicokinetics of a phosphorothioate oligonucleotide against the c-myc oncogene in cynomolgus monkeys. Antisense Nucleic Acid Drug Dev. 2001, 11, 155-163. [CrossRef]

270. Devi, G.R.; Beer, T.M.; Corless, C.L.; Arora, V.; Weller, D.L.; Iversen, P.L. In vivo bioavailability and pharmacokinetics of a c-MYC antisense phosphorodiamidate morpholino oligomer, AVI-4126, in solid tumors. Clin. Cancer Res. 2005, 11, 3930-3938. [CrossRef]

271. Miller, A.J.; Chang, A.; Cunningham, P.N. Chronic Microangiopathy Due to DCR-MYC, a Myc-Targeted Short Interfering RNA. Am. J. Kidney Dis. 2020, 75, 513-516. [CrossRef]

272. Shaat, H.; Mostafa, A.; Moustafa, M.; Gamal-Eldeen, A.; Emam, A.; El-Hussieny, E.; Elhefnawi, M. Modified gold nanoparticles for intracellular delivery of anti-liver cancer siRNA. Int. J. Pharm. 2016, 504, 125-133. [CrossRef] [PubMed]

273. Conde, J.; Tian, F.; Hernandez, Y.; Bao, C.; Cui, D.; Janssen, K.P.; Ibarra, M.R.; Baptista, P.V.; Stoeger, T.; De la Fuente, J.M. In vivo tumor targeting via nanoparticle-mediated therapeutic siRNA coupled to inflammatory response in lung cancer mouse models. Biomaterials 2013, 34, 7744-7753. [CrossRef]

274. Zhu, Q.; Feng, C.; Liao, W.; Zhang, Y.; Tang, S. Target delivery of MYCN siRNA by folate-nanoliposomes delivery system in a metastatic neuroblastoma model. Cancer Cell Int. 2013, 13, 65. [CrossRef]

275. Zhang, Y.; Peng, L.; Mumper, R.J.; Huang, L. Combinational delivery of c-myc siRNA and nucleoside analogs in a single, synthetic nanocarrier for targeted cancer therapy. Biomaterials 2013, 34, 8459-8468. [CrossRef] [PubMed]

276. Whitfield, J.R.; Beaulieu, M.E.; Soucek, L. Strategies to Inhibit Myc and Their Clinical Applicability. Front. Cell Dev. Biol. 2017, 5, 10. [CrossRef]

277. Filippakopoulos, P.; Knapp, S. Targeting bromodomains: Epigenetic readers of lysine acetylation. Nat. Rev. Drug Discov. 2014, 13, 337-356. [CrossRef] [PubMed]

278. Kulikowski, E.; Rakai, B.D.; Wong, N.C.W. Inhibitors of bromodomain and extra-terminal proteins for treating multiple human diseases. Med. Res. Rev. 2020. [CrossRef] 
279. Filippakopoulos, P.; Qi, J.; Picaud, S.; Shen, Y.; Smith, W.B.; Fedorov, O.; Morse, E.M.; Keates, T.; Hickman, T.T.; Felletar, I.; et al. Selective inhibition of BET bromodomains. Nature 2010, 468, 1067-1073. [CrossRef]

280. Dawson, M.A.; Prinjha, R.K.; Dittmann, A.; Giotopoulos, G.; Bantscheff, M.; Chan, W.I.; Robson, S.C.; Chung, C.W.; Hopf, C.; Savitski, M.M.; et al. Inhibition of BET recruitment to chromatin as an effective treatment for MLL-fusion leukaemia. Nature 2011, 478, 529-533. [CrossRef] [PubMed]

281. Mirguet, O.; Gosmini, R.; Toum, J.; Clement, C.A.; Barnathan, M.; Brusq, J.M.; Mordaunt, J.E.; Grimes, R.M.; Crowe, M.; Pineau, O.; et al. Discovery of epigenetic regulator I-BET762: Lead optimization to afford a clinical candidate inhibitor of the BET bromodomains. J. Med. Chem. 2013, 56, 7501-7515. [CrossRef] [PubMed]

282. Boi, M.; Gaudio, E.; Bonetti, P.; Kwee, I.; Bernasconi, E.; Tarantelli, C.; Rinaldi, A.; Testoni, M.; Cascione, L.; Ponzoni, M.; et al. The BET Bromodomain Inhibitor OTX015 Affects Pathogenetic Pathways in Preclinical B-cell Tumor Models and Synergizes with Targeted Drugs. Clin. Cancer Res. 2015, 21, 1628-1638. [CrossRef] [PubMed]

283. Faivre, E.J.; McDaniel, K.F.; Albert, D.H.; Mantena, S.R.; Plotnik, J.P.; Wilcox, D.; Zhang, L.; Bui, M.H.; Sheppard, G.S.; Wang, L.; et al. Selective inhibition of the BD2 bromodomain of BET proteins in prostate cancer. Nature 2020, 578, 306-310. [CrossRef] [PubMed]

284. Tanaka, M.; Roberts, J.M.; Seo, H.S.; Souza, A.; Paulk, J.; Scott, T.G.; DeAngelo, S.L.; Dhe-Paganon, S.; Bradner, J.E. Design and characterization of bivalent BET inhibitors. Nat. Chem. Biol. 2016, 12, 1089-1096. [CrossRef] [PubMed]

285. Alqahtani, A.; Choucair, K.; Ashraf, M.; Hammouda, D.M.; Alloghbi, A.; Khan, T.; Senzer, N.; Nemunaitis, J. Bromodomain and extra-terminal motif inhibitors: A review of preclinical and clinical advances in cancer therapy. Future Sci. OA 2019, 5, FSO372. [CrossRef] [PubMed]

286. Rathert, P.; Roth, M.; Neumann, T.; Muerdter, F.; Roe, J.S.; Muhar, M.; Deswal, S.; Cerny-Reiterer, S.; Peter, B.; Jude, J.; et al. Transcriptional plasticity promotes primary and acquired resistance to BET inhibition. Nature 2015, 525, 543-547. [CrossRef]

287. Fong, C.Y.; Gilan, O.; Lam, E.Y.; Rubin, A.F.; Ftouni, S.; Tyler, D.; Stanley, K.; Sinha, D.; Yeh, P.; Morison, J.; et al. BET inhibitor resistance emerges from leukaemia stem cells. Nature 2015, 525, 538-542. [CrossRef] [PubMed]

288. Shi, X.; Mihaylova, V.T.; Kuruvilla, L.; Chen, F.; Viviano, S.; Baldassarre, M.; Sperandio, D.; Martinez, R.; Yue, P.; Bates, J.G.; et al. Loss of TRIM33 causes resistance to BET bromodomain inhibitors through MYC- and TGF-beta-dependent mechanisms. Proc. Natl. Acad. Sci. USA 2016, 113, E4558-E4566. [CrossRef] [PubMed]

289. Carra, G.; Nicoli, P.; Lingua, M.F.; Maffeo, B.; Cartella, A.; Circosta, P.; Brancaccio, M.; Parvis, G.; Gaidano, V.; Guerrasio, A.; et al. Inhibition of bromodomain and extra-terminal proteins increases sensitivity to venetoclax in chronic lymphocytic leukaemia. J. Cell Mol. Med. 2020, 24, 1650-1657. [CrossRef]

290. Peirs, S.; Frismantas, V.; Matthijssens, F.; Van Loocke, W.; Pieters, T.; Vandamme, N.; Lintermans, B.; Dobay, M.P.; Berx, G.; Poppe, B.; et al. Targeting BET proteins improves the therapeutic efficacy of BCL-2 inhibition in T-cell acute lymphoblastic leukemia. Leukemia 2017, 31, 2037-2047. [CrossRef]

291. Li, W.; Gupta, S.K.; Han, W.; Kundson, R.A.; Nelson, S.; Knutson, D.; Greipp, P.T.; Elsawa, S.F.; Sotomayor, E.M.; Gupta, M. Targeting MYC activity in double-hit lymphoma with MYC and BCL2 and/or BCL6 rearrangements with epigenetic bromodomain inhibitors. J. Hematol. Oncol. 2019, 12, 73. [CrossRef]

292. Fiskus, W.; Cai, T.; DiNardo, C.D.; Kornblau, S.M.; Borthakur, G.; Kadia, T.M.; Pemmaraju, N.; Bose, P.; Masarova, L.; Rajapakshe, K.; et al. Superior efficacy of cotreatment with BET protein inhibitor and BCL2 or MCL1 inhibitor against AML blast progenitor cells. Blood Cancer J. 2019, 9, 4. [CrossRef]

293. Ramsey, H.E.; Greenwood, D.; Zhang, S.; Childress, M.; Arrate, M.P.; Gorska, A.E.; Fuller, L.; Zhao, Y.; Stengel, K.; Fischer, M.A.; et al. BET Inhibition Enhances the Antileukemic Activity of Low-dose Venetoclax in Acute Myeloid Leukemia. Clin. Cancer Res. 2020. [CrossRef] [PubMed]

294. Zhang, S.; Zhao, Y.; Heaster, T.M.; Fischer, M.A.; Stengel, K.R.; Zhou, X.; Ramsey, H.; Zhou, M.M.; Savona, M.R.; Skala, M.C.; et al. BET inhibitors reduce cell size and induce reversible cell cycle arrest in AML. J. Cell Biochem. 2018. [CrossRef] [PubMed]

295. Esteve-Arenys, A.; Valero, J.G.; Chamorro-Jorganes, A.; Gonzalez, D.; Rodriguez, V.; Dlouhy, I.; Salaverria, I.; Campo, E.; Colomer, D.; Martinez, A.; et al. The BET bromodomain inhibitor CPI203 overcomes resistance to ABT-199 (venetoclax) by downregulation of BFL-1/A1 in in vitro and in vivo models of MYC+/BCL2+ double hit lymphoma. Oncogene 2018, 37, 1830-1844. [CrossRef]

296. Cummin, T.E.C.; Cox, K.L.; Murray, T.D.; Turaj, A.H.; Dunning, L.; English, V.L.; Fell, R.; Packham, G.; Ma, Y.; Powell, B.; et al. BET inhibitors synergize with venetoclax to induce apoptosis in MYC-driven lymphomas with high BCL-2 expression. Blood Adv. 2020, 4, 3316-3328. [CrossRef]

297. Bui, M.H.; Lin, X.; Albert, D.H.; Li, L.; Lam, L.T.; Faivre, E.J.; Warder, S.E.; Huang, X.; Wilcox, D.; Donawho, C.K.; et al. Preclinical Characterization of BET Family Bromodomain Inhibitor ABBV-075 Suggests Combination Therapeutic Strategies. Cancer Res. 2017, 77, 2976-2989. [CrossRef] [PubMed]

298. Lam, L.T.; Lin, X.; Faivre, E.J.; Yang, Z.; Huang, X.; Wilcox, D.M.; Bellin, R.J.; Jin, S.; Tahir, S.K.; Mitten, M.; et al. Vulnerability of Small-Cell Lung Cancer to Apoptosis Induced by the Combination of BET Bromodomain Proteins and BCL2 Inhibitors. Mol. Cancer Ther. 2017, 16, 1511-1520. [CrossRef] [PubMed]

299. Wang, H.; Hong, B.; Li, X.; Deng, K.; Li, H.; Yan Lui, V.W.; Lin, W. JQ1 synergizes with the Bcl-2 inhibitor ABT-263 against MYCN-amplified small cell lung cancer. Oncotarget 2017, 8, 86312-86324. [CrossRef] 
300. Wu, Z.; Hu, Z.; Han, X.; Li, Z.; Zhu, Q.; Wang, Y.; Zheng, Q.; Yan, J. The BET-Bromodomain Inhibitor JQ1 synergized ABT-263 against colorectal cancer cells through suppressing c-Myc-induced miR-1271-5p expression. Biomed. Pharmacother. 2017, 95, 1574-1579. [CrossRef] [PubMed]

301. Lasorsa, E.; Smonksey, M.; Kirk, J.S.; Rosario, S.; Hernandez-Ilizaliturri, F.J.; Ellis, L. Mitochondrial protection impairs BET bromodomain inhibitor-mediated cell death and provides rationale for combination therapeutic strategies. Cell Death Dis. 2015, 6, e2014. [CrossRef]

302. Ishida, C.T.; Bianchetti, E.; Shu, C.; Halatsch, M.E.; Westhoff, M.A.; Karpel-Massler, G.; Siegelin, M.D. BH3-mimetics and BET-inhibitors elicit enhanced lethality in malignant glioma. Oncotarget 2017, 8, 29558-29573. [CrossRef]

303. Tseng, H.Y.; Dreyer, J.; Emran, A.A.; Gunatilake, D.; Pirozyan, M.; Cullinane, C.; Dutton-Regester, K.; Rizos, H.; Hayward, N.K.; McArthur, G.; et al. Co-targeting bromodomain and extra-terminal proteins and MCL1 induces synergistic cell death in melanoma. Int. J. Cancer 2020, 147, 2176-2189. [CrossRef]

304. Xu, Z.; Sharp, P.P.; Yao, Y.; Segal, D.; Ang, C.H.; Khaw, S.L.; Aubrey, B.J.; Gong, J.; Kelly, G.L.; Herold, M.J.; et al. BET inhibition represses miR17-92 to drive BIM-initiated apoptosis of normal and transformed hematopoietic cells. Leukemia 2016, 30, 1531-1541. [CrossRef] [PubMed]

305. Kim, S.R.; Lewis, J.M.; Cyrenne, B.M.; Monico, P.F.; Mirza, F.N.; Carlson, K.R.; Foss, F.M.; Girardi, M. BET inhibition in advanced cutaneous T cell lymphoma is synergistically potentiated by BCL2 inhibition or HDAC inhibition. Oncotarget 2018, 9, $29193-29207$. [CrossRef] 